\title{
The locomotory apparatus and paraxial swimming in fossil and living marine reptiles: comparing Nothosauroidea, Plesiosauria, and Chelonioidea
}

\author{
Anna Krahl ${ }^{1,2,3}$ (D) \\ Received: 30 May 2019 / Accepted: 22 April 2021 / Published online: 1 June 2021 \\ (c) The Author(s) 2021
}

\begin{abstract}
The terrestrial origins of the diapsid Sauropterygia and Testudines are uncertain, with the latter being highly controversially discussed to this day. For only $15 \mathrm{Ma}$, Nothosauroidea lived in shallow-marine seas of the Triassic. Contrastingly, the pelagic Plesiosauria evolved in the Late Triassic, dispersed globally, and inhabited the oceans of the Jurassic and Cretaceous for approximately $135 \mathrm{Ma}$. Since the Cretaceous ( 100 Ma), Chelonioidea, the modern sea turtles, have populated the oceans. All three groups evolved aquatic paraxial locomotion. Nothosaurs swam with their foreflippers, supported by the swimming tail. Plesiosaurs are the only tetrapods to have ever evolved four hydrofoil-like flippers. The plesiosaur flipper beat cycle has been debated for nearly two centuries. The different proposed locomotory styles (rowing, rowing-flight, underwater flight) are discussed in this review. A fourth gait that is employed by Carettochelys insculpta, which combines rowing and flying, is introduced. The osteology of the locomotory apparatus of nothosaurs and plesiosaurs is reviewed and compared to that of extant underwater-flying Chelonioidea. In conclusion, underwater flight remains the favoured locomotory style for plesiosaurs. Also, the review reveals that nothosaur locomotion has largely remained unstudied. Further, our understanding of joint morphologies and mobilities of the foreflipper in nothosaurs, plesiosaurs, and even recent sea turtles, and of the hindflipper in plesiosaurs, is very limited. It is crucial to the discussion of locomotion, to find out, if certain limb cycles were even possible, as evidence seems to point to the improbability of a rowing motion because of limited humerus and femur long axis rotation in plesiosaurs.
\end{abstract}

Keywords Nothosauroidea $\cdot$ Plesiosauria $\cdot$ Chelonioidea $\cdot$ Mode of locomotion $\cdot$ Rowing $\cdot$ Underwater flight

Handling Editor: Walter Joyce.

Anna Krahl

anna.krahl@rub.de

1 Biomechanics Research Group, Faculty of Mechanical Engineering, Lehrstuhl für Produktentwicklung, RuhrUniversität Bochum, Universitätsstr. 150, 44801 Bochum, Germany

2 Section of Paleontology, Institute of Geoscience, Rheinische Friedrich-Wilhelms Universität Bonn, Nußallee 8, 53115 Bonn, Germany

3 Fachbereich Geowissenschaften an der Eberhard-Karls-Universität Tübingen, Hölderlinstraße 12, 72074 Tübingen, Germany

\section{Evolution of Nothosauroidea and Plesiosauria (Eosauropterygia) and Chelonioidea}

\section{Phylogeny, ecology, and distribution of Nothosauroidea and Plesiosauria}

Sauropterygia were amongst the first fossil reptiles subjected to paleontological research (de la Beche and Conybeare 1821; Owen 1840; von Meyer 1847-1855). Since then, researchers have studied not only their morphology and phylogeny, but also different aspects of their biology (Taylor 1989; Cruickshank et al. 1991; Storrs 1993; Buchy et al. 2006; Araújo and Polcyn 2013; Foffa et al. 2014a; Klein et al. 2016; Neenan et al. 2017; O'Keefe et al. 2017; Wintrich et al. 2017b; Nagesan et al. 2018; Troelsen et al. 2019). Yet many questions remain to be answered. 
Comparable to Cetacea (Houssaye et al. 2015), Sauropterygian evolution covers a spectrum of gradual adaptations from shallow-marine benthic (Rieppel 1995) to pelagic lifestyles (Rieppel 2000; Wintrich et al. 2017a). These are accompanied by fundamental restructuring of the locomotory apparatus and thus the mode of locomotion. Three sauropterygian taxa, namely Placodontia, Nothosauroidea, and Plesiosauroidea, employed paraxial locomotion. The following text will focus on evaluating what we know about the locomotion of two of them, namely Nothosauroidea and Plesiosauria, by comparing them to a recent functional analogue within the reptiles, the Chelonioidea. Chelonioidea were chosen as functional analogue because they fly underwater. Sea turtles were given the favor over penguins because they do not have a reduced digital number and because they do not have the highly derived avian flight mechanism (i.e., the acrocoracohumeral ligament and the osteological complex that resolves around it) that penguins and other birds have (Baier et al. 2007).

Sauropterygia are marine Diapsida, which split into a series of clades that diversified in the Triassic (Placodontia, Pachypleurosauria, Nothosauroidea, and Pistosauroidea) and a single clade that diversified during the Jurassic and Cretaceous (Plesiosauria). The origins of Sauropterygia remain unresolved (Fig. 1a, b). However, depending on the author, they are either basal Lepidosauromorpha (Rieppel and Reisz 1999) (Fig. 1c), basal Archosauromorpha (Merck 1997) (Fig. 1b), or a sister group to Archosauromorpha and Lepidosauromorpha (Neenan et al. 2013) (Fig. 1a). Nothosauroidea include the genera Simosaurus, Germanosaurus, Nothosaurus, and Lariosaurus, and is the sister group of Pachypleurosauria (Rieppel 2000; Holmes et al. 2008) (Fig. 2a-c), whose monophyly has been in doubt since Holmes et al. (2008) work on Keichousaurus. However, integration of recent Chinese sauropterygian findings into analyses mostly resulted in unstable phylogenetic relationships of basal Sauropterygia (Neenan et al. 2015; Cheng et al. 2016) (Fig. 1b-c). Nothosauroidea existed only for a very limited time period in the Triassic, from the late Olenekian to the early Carnian (about $15 \mathrm{Ma}$ ) (Hagdorn and Rieppel 1999; Jiang et al. 2014). Nothosaurs lived in coastal shallow-marine epicontinental habitats (Hagdorn et al. 1991; Hagdorn and Rieppel 1999; Hagdorn and Simon 2005; Rieppel 1999; Neenan et al. 2017) and were carnivorous. Their dentition indicates that they were probably mainly specialized for piscivory (Rieppel 2002; Shang 2007). Nothosaurus fossils have been found in Europe (Klein et al. 2015; Chaves et al. 2016; Miguel Chaves et al. 2018), China (e.g., Liu et al. 2014; Lin et al. 2017), Tunisia (Rieppel 1997), and Israel (Rieppel et al. 1997).

Basal Sauropterygia remained stratigraphically restricted to the Triassic (Bardet 1994; Hagdorn and Rieppel 1999; Rieppel 1999). Contrastingly, plesiosaurs were long
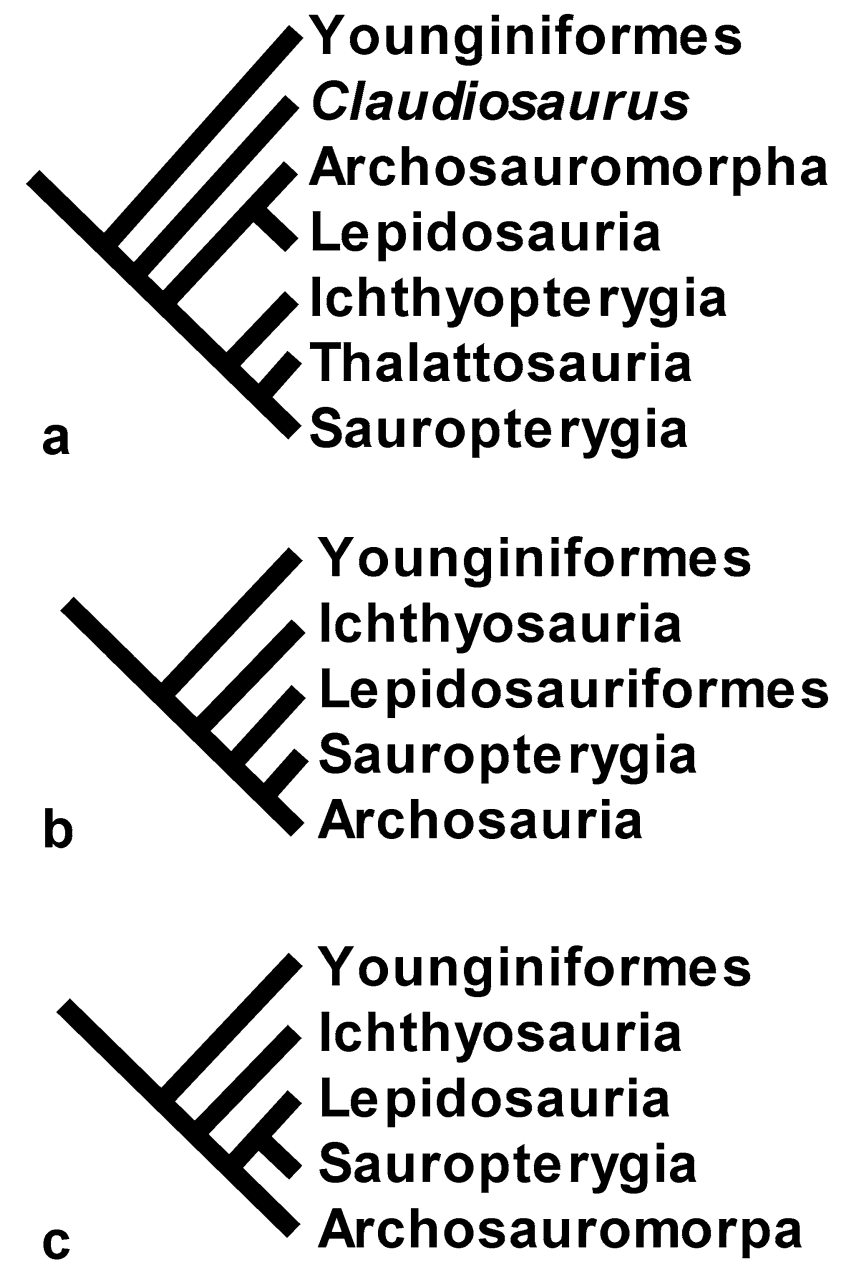

Fig. 1 Hypotheses of relationships of Sauropterygia. a Sauropterygia is the sistergroup of Thalattosauria, after Neenan et al. (2013); b Sauropterygia is the sistergroup of Archosauria, after Merck (1997); c Sauropterygia is the sistergroup of Lepidosauria, after Rieppel and Reisz (1999)

considered to have evolved in the Late Triassic (Bardet 1994; Rieppel 1999; O’Keefe 2001a; Fabbri et al. 2013) but conclusive fossil evidence was lacking until recently (Wintrich et al. 2017a). These new fossils and new phylogenetic hypotheses (Benson et al. 2012) indicate that plesiosaurs had quickly reached a high diversity and global distribution in the Jurassic period (Bardet 1994; Rieppel 1999; O'Keefe 2001a; Ketchum and Benson 2010; Bardet et al. 2014) and had died out at the K/Pg boundary (Bardet 1994; Motani 2009; Vincent et al. 2011, 2013).

In the traditional view, Plesiosauria was split into two monophyletic groups: plesiosaurs (long neck and small head) and pliosaurs (short neck and large head) (Williston 1914; Brown 1981; Druckenmiller and Russell 2008; Smith and Dyke 2008). However, modern cladistic analyses prove this dichotomy to be invalid. In contrast, these two plesiosaur bodyplans rather represent morphotypes, plesio- and 


\section{Placodontia
Pachypleurosauria
Nothosauroidea
Pistosauroidea}

\section{Placodontia
Pachypleurosauria
Nothosauroidea
Pistosauroidea}

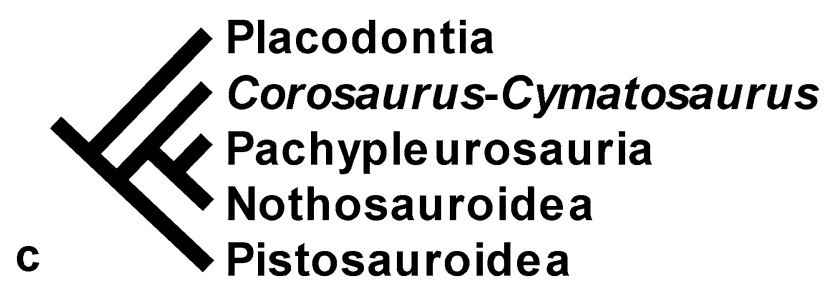

Fig. 2 Selection of representative sauropterygian ingroup phylogenies; a showing Placodontia as the most basal sauropterygians, followed by Pachypleurosauria, Nothosauria and Pistosauroidea, after Rieppel (2000); b Shang and Li (2015) differ from a in that Pachypleurosauria and Nothosauria form a clade, after Shang and $\mathrm{Li}$ (2015); c Placodontia remain the most basal and Pistosauroidea the most derived sauropterygians, while Corosaurus-Cymatosaurus (usually found as basal pistosauroids) are at the base of a clade comprising Pachypleurosauria and Nothosauria as well, after Neenan et al. (2013)

pliosauromorphs, that evolved several times convergently (O'Keefe 2002; O'Keefe and Carrano 2005; Ketchum and Benson 2010; Benson and Druckenmiller 2014). These two extreme morphotypes evolved from basal intermediate Late Triassic and Early Jurassic forms during the Jurassic and Cretaceous. Pliosauromorphs usually have larger hindflippers than foreflippers (O'Keefe 2002; O' Keefe and Carrano 2005) and are generally considered as fast, powerful, and agile predators that chase their prey down (Taylor 1981; Massare 1988; O'Keefe 2001b). Plesiosauromorphs generally have larger foreflippers than hindflippers (O'Keefe 2002; O' Keefe and Carrano 2005) and are generally regarded as ambush predators (Taylor 1981; Massare 1988) and efficient, moderately fast long-distance swimmers (O'Keefe 2001b). Plesiosaurs lived in open marine habitats and to a minor extent in brackish, and fluvial habitats (Kear et al. 2006). They were all faunivorous, but showed quite different dietary preferences, as is suggested by their dentition and by fossil gastric contents (Sato and Tanabe 1998; Cicimurri and Everhart 2001; McHenry et al. 2005; O' Keefe et al. 2017). Foffa et al. (2014b) suggested that some pliosauromorphs might also be generalists. Filter feeding has also been recently proposed for an elasmosaur (O'Keefe et al. 2017). It is noteworthy that plesiosaur skeletons are often associated with gastroliths. Whether gastroliths had an influence on the plesiosaur's buoyancy, or whether they aided in food processing has not been clarified yet (see Wings 2007 for review; Schmeisser and Gillette 2009; O'Gorman et al. 2013, 2014). Jurassic and Cretaceous plesiosaurs have been found on all of today's continents and were globally distributed in the Mesozoic (for review, see Bardet et al. 2014: 875, fig. 4).

\section{Phylogeny, ecology, and distribution of recent Chelonioidea}

Turtle origins remain still highly controversial (Hill 2005 and Iwabe et al. 2005 for a brief summary; for more detail e.g., Lyson et al. 2010; Lyson et al. 2012; Carroll 2013; Wang et al. 2013; Field et al. 2014; Crawford et al. 2015; Schoch and Sues 2015; Pereira et al. 2017; Lyson and Bever 2020) (Fig. 3a-d). Chelonioidea are neither pleurodire nor cryptodire turtles and pose one of various convergently evolved clades within Testudines that adapted to the marine environment (Evers and Benson 2019) (Fig. 3d). Recent Chelonioidea are composed of two families, Dermochelyidae and Cheloniidae. The first family includes only one extant species, namely Dermochelys coriacea, and the second comprises all other six extant species (Chelonia mydas, Natator depressus, Eretmochelys imbricata, Caretta caretta, Lepidochelys olivacea, and L. kempii) (Naro-Maciel et al. 2008).

Chelonioidea, like Plesiosauria, are a long-lived lineage of secondarily aquatic reptiles (Bardet 1994; Motani 2009; Vincent et al. 2011, 2013). Similarly to plesiosaurs (see also Bardet 1994; Rieppel 1999; O’Keefe 2001a; O'Keefe and Carrano 2005; Ketchum and Benson 2010; Bardet et al. 2014), Chelonioidea are globally distributed although they are restricted to warmer waters as they are ectotherms. Dermochelys coriacea poses the only exception because it has an increased body core temperature (gigantothermic), lives in colder waters, and is the only recent truly pelagic sea turtle (Davenport et al. 2015).

Chelonioidea have inhabited the oceans since the middle Cretaceous ( $100 \mathrm{Ma})$ or possibly since the Early Cretaceous ( $145 \mathrm{Ma}$ ) (Evers and Benson 2019) to the present day. Presumably the behaviour of recent chelonioids resembles that of their fossil ancestors closely (Motani 2009). Juveniles of e.g., Caretta caretta hatch on a beach, head in the "frenzy" towards the ocean, and spend their first years in the open ocean. These years are called "lost years" by Carr (1952) because it was unknown where the hatchlings and juveniles went and how they lived. Juvenile chelonioids are carried by oceanic currents with sargassum rafts, which serve as shelters and supply them with food. The currents bring them to new habitats. As subadults, they migrate to 
Fig. 3 a-d Hypotheses of relationships of Testudines based on Iwabe et al. (2005) a as sistergroup to Lepidosauria and Archosauria; b as sistergroup to Archosauria; c as sistergroup to Lepidosauria, $\mathbf{d}$ as sistergroup to Crocodylia; e most recent phylogeny depicting Testudines interrelationships, after Crawford et al. (2015)
Testudines
Lepidosauria
a
Archosauria
b
Le pidosauria
Testudines
Archosauria
Archosauria
Testudines
cepidosauria

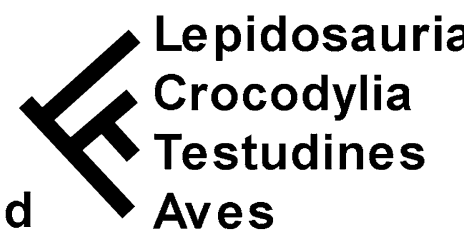

\section{Pleurodira Trionychia Testudinoidea Chelonioidea e Chelydroidea}

coastal waters (Frick et al. 2009). When they reach sexual maturity, they migrate hundreds of kilometres across the ocean to return to their birthplace, to mate and nest (Meylan 1982; Limpus et al. 1992).

\section{Sauropterygian (Nothosauroidea and Plesiosauria) and chelonioid locomotion}

\section{Locomotory apparatus and locomotion of Sauropterygia (Nothosauroidea and Plesiosauria)}

\section{Nothosauroidea}

Osteology_Nothosaurs have a long, laterally compressed swimming tail (Carroll and Gaskill 1985; Sues 1987). The trunk region shows several characteristics for secondary stiffening, e.g., the densely packed gastralia that restrict lateral undulation (Storrs 1993), the zygosphene-zygantrum articulations which are accessory articulations of the vertebrae acting against rotatory moments (Romer 1976; Carroll and Gaskill 1985), and the platycoelous vertebrae (Rieppel 2000) that limit the motion range in every vertebral joint (Storrs 1993). The ventrally lying bones of the nothosaur pectoral and pelvic girdle (clavicula, coracoid, pubis, ischium) are relatively enlarged (Kuhn-Schnyder 1987).

The pre-axial margin of the humeri is straight, as in pachypleurosaurs. The humeral shaft of nothosaur humeri is curved so the proximal and distal ends are somewhat bent post-axially (Bickelmann and Sander 2008; Klein 2010). The mid-shaft cross section is triangular (Bickelmann and
Sander 2008; Klein 2010; Hugi 2011; Krahl et al. 2013; Klein et al. 2016), i.e., the humerus is thicker pre-axially than postaxially. The ventral side of the humeral shaft is roughly flat (Bickelmann and Sander 2008; Klein 2010) (Fig. 4a, b). The overall elaborate morphology of the nothosaur humeri was likely not exclusively determined by humerus function, but possibly by sexual dimorphism (Renesto 1993; Bickelmann and Sander 2008; Klein 2010) as in pachypleurosaurs (Sander 1989; Cheng et al. 2004; Motani et al. 2015; Griebeler and Klein 2019).

Radius and ulna are short and especially the ulna is dorsoventrally flattened (Kuhn-Schnyder 1987; Storrs 1993; Rieppel 1998; Bickelmann and Sander 2008) (Fig. 5a). In nothosaurs, carpals and tarsals are often poorly ossified. Metacarpal I and V have migrated proximally into the row of the distal carpals (Kuhn-Schnyder 1987). Kuhn-Schnyder (1987) suggests that metacarpal V could have been spread to extend the web of the hand. Some nothosaur taxa display hyperphalangy (Storrs 1993; Rieppel 1998). Overall, the foreflippers are round or paddle-shaped and probably had webbed digits (Storrs 1993).

Joints - The glenoid articulation of nothosaurs has not been closely studied so far in terms of degrees of freedom. Storrs (1993) suggests that the rather oval (long axis oriented in dorsoventral direction) glenoid fossa seems to exclude long axis rotation of the humerus which has an oval articulation surface with a pre-axially to post-axially directed long axis (Fig. 4f). Further, he suggested that nothosaurs show secondarily stiffened foreflippers (Storrs 1993), e.g., a stiffened 

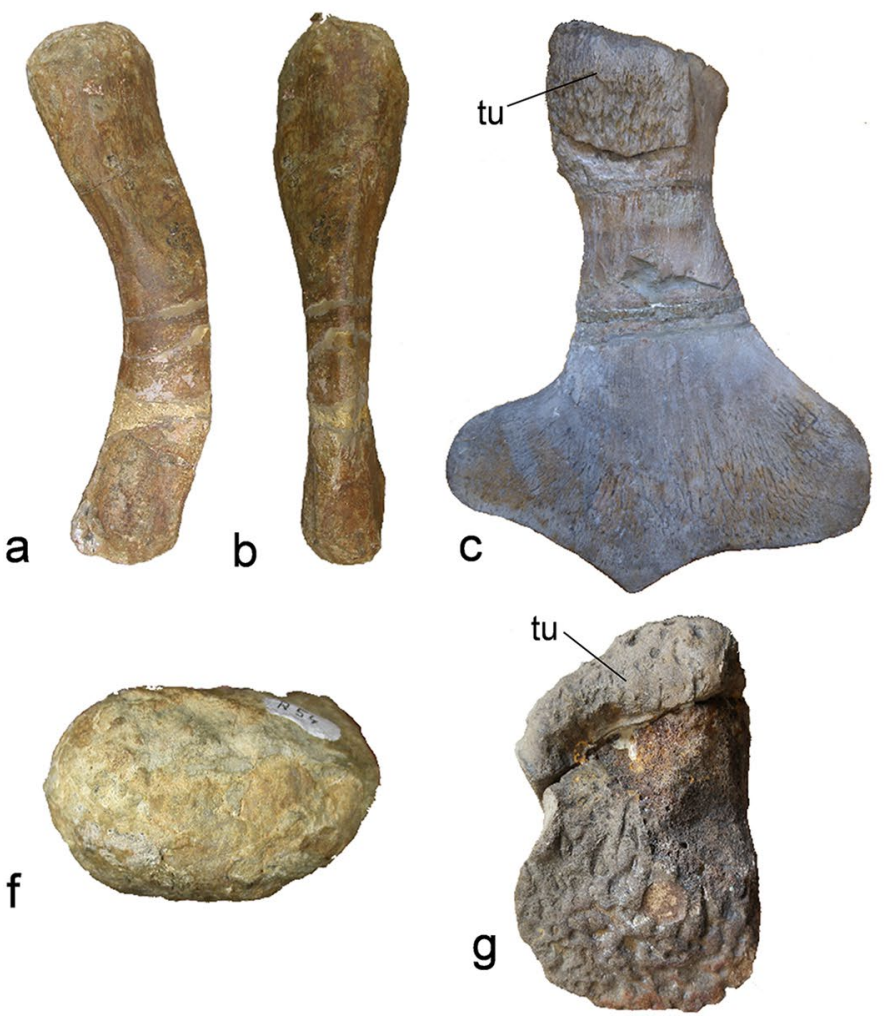

Fig. 4 Overview over nothosaur, plesiosaur, and cheloniid humeri and plesiosaur femur and their proximal articulation surfaces. Nothosaurus mirabilis humerus (STIPB R 54) in a dorsal view and b in pre-axial view. Note the marked, straight pre-axial ridge, and the flatter ventral side on the right (The minimal pre-axial curvature derives from the reconstruction of the bone with plaster). c right Cryptoclidus eurymerus (STIPB 324) humerus. d Left Cryptoclidus eurymerus (STIPB 324) femur. e Right Chelonia mydas (ZFMK 70222) humerus. f Humeral head of STIPB R 54 has a smooth articulation

elbow joint (Kuhn-Schnyder 1987). In general, nothosaur foreflipper mobility has not been investigated in detail.

\section{Mode of locomotion}

In nothosaurs, the long swimming tail probably served as main propulsive organ with which they swam by lateral undulation. Nonetheless, authors agree with Carroll and Gaskill (1985) that the foreflippers played an important role in propulsion since they are strongly morphologically (Carroll and Gaskill 1985; Kuhn-Schnyder 1987; Sues 1987; Storrs 1993) and histologically derived (Krahl et al. 2013; Klein et al. 2016). As opposed to foreflipper morphology, nothosaur hindflipper morphology is plesiomorphic, and it thus is assumed that hindflippers were employed in manoeuvering (Storrs 1993). This hypothesis was corroborated by Krahl et al. (2013) and Klein et al. (2016) by studying Nothosaurus long bones histologically. They showed that humeri, unlike femora, of large nothosaur species show a
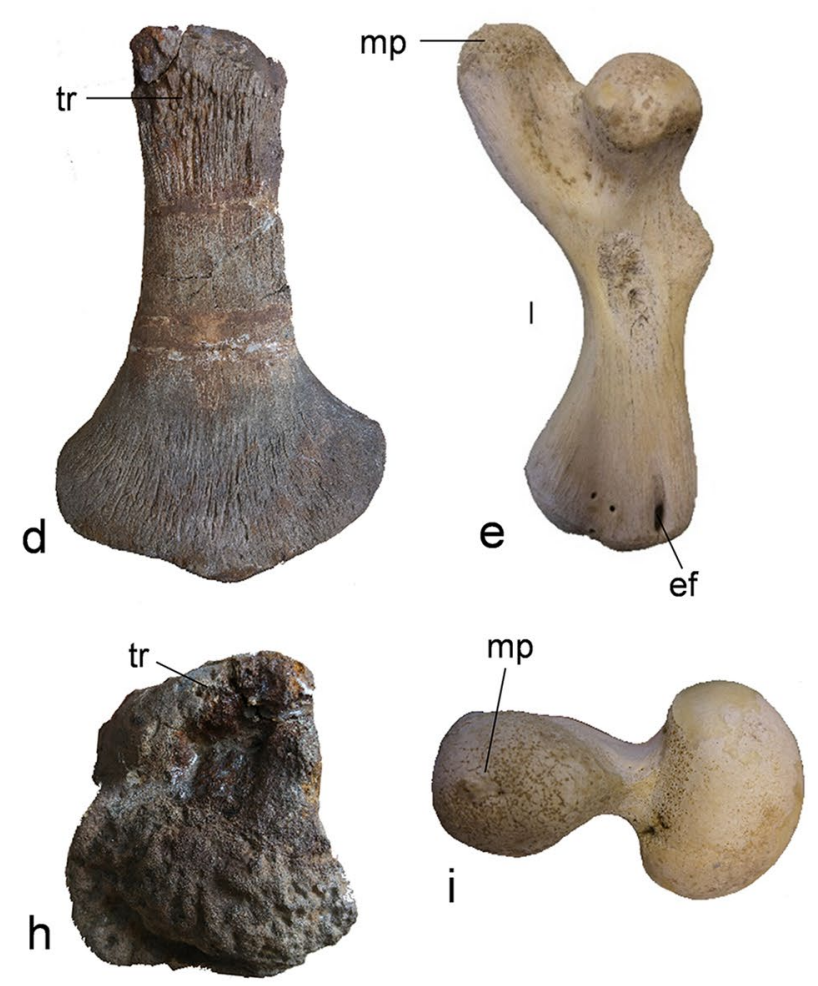

surface. $\mathbf{g}$ The humeral head and $\mathbf{h}$ the femoral head of STIPB R 324 show a rough proximal articulation surface with deep pits. i The proximal articulation surface of the humeral head of ZFMK 70222 has a smooth surface. The medial process has a smooth but pitted surface. Here the musculus coracobrachialis magnus inserts fibrocartilagenously (see Krahl et al. 2019 for more information) Not to scale. ef entepicondylar foramen, $m p$ medial process, $t r$ trochanter, $t u$ tuberosity

remarkable microanatomical specialization, i.e., the cortical bone is extremely reduced in thickness. The cortical thickness is comparable to that of aerial birds. This was interpreted as adjustments of the foreflippers to torsional forces, suggesting a complex movement cycle, possibly underwater flight (Krahl et al. 2013; Klein et al. 2016). Further evidence for this hypothesis is provided by nothosaur trace fossils described by Zhang et al. (2014).

\section{Plesiosauria}

Osteology-The locomotory apparatus of Plesiosauria is morphologically highly derived over that of the more basal sauropterygians, e.g., nothosaurs. Plesiosaurs have a greatly shortened tail (Taylor 1989; Wintrich et al. 2017a), with possibly a tail fin (for review see Smith 2013) and a greatly shortened trunk. The latter is secondarily stiffened by densely packed gastralia and much enlarged plate-like girdle elements (scapula, coracoid, pubis, ischium), similar 

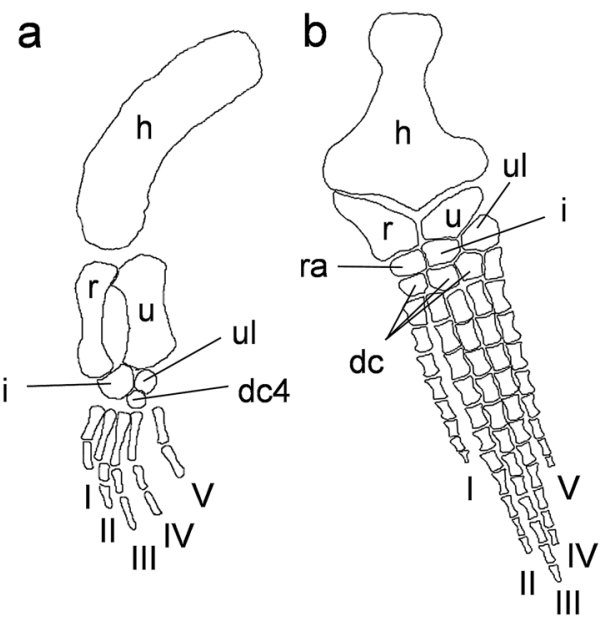

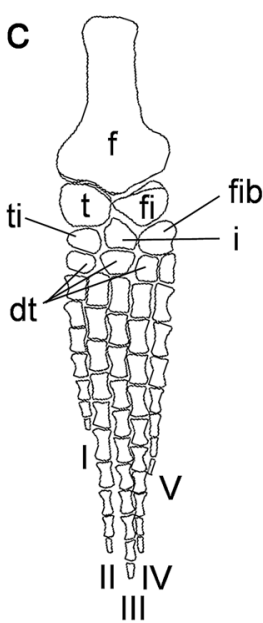

III
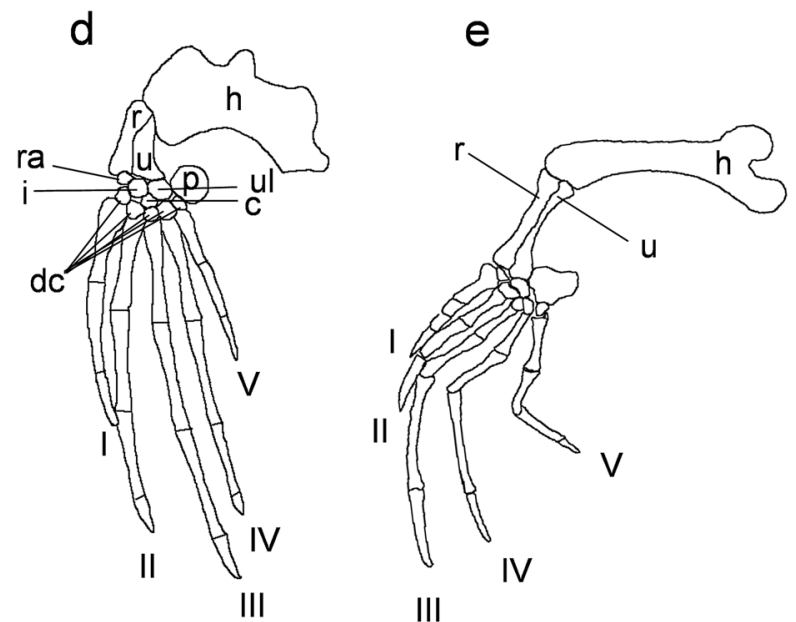

Fig. 5 Contour drawings of the osteology of flippers of aquatic turtles and sauropterygians. a Foreflipper of Lariosaurus balsami (Nothosauroidea) humerus and manus (redrawn from Rieppel (1998) and combined in one picture; b foreflipper of Cryptoclidus eurymerus (Plesiosauria), based on STIPB R 324; c hindflipper of Cryptoclidus eurymerus based on STIPB R 324; $\mathbf{d}$ foreflipper of Dermochelys coriacea (Chelonioidea), redrawn after Wyneken (1997); e foreflipper of Carettochelys insculpta, redrawn and mirrored after Rivera et al.

to the convergently evolved turtle plastron (Sues 1987; Taylor 1989; Storrs 1993). The dorsal portion of the scapula as well as the ilium are much reduced in size relative to the ventrally lying bones of the non-homologous pectoral and pelvic girdle, which are much enlarged (Frey and Riess 1982; Tarsitano and Riess 1982; Godfrey 1984).

Dorsally, plesiosaur humeri and femora have a processlike structure which is called tuberosity in the former and trochanter in the latter (Andrews 1910). The capitulum of both bones is generally round in cross section. Distally, both bones are increasingly dorsoventrally flattened and pre-axially to post-axially expanded (Andrews 1910) (Fig. 4c, d, g, h). How humeri and femora expand distally may vary across taxa: Sometimes the pre-axial margin is rather straight and the post-axial margin is expanded and curved post-axially (Druckenmiller and Russell 2008; Schumacher and Martin 2015; Delsett et al. 2016; Sachs et al. 2016) (Fig. 6a, d), sometimes the both the pre- and post-axial margin are expanded and curved pre-axially and post-axially (Hawkins 1840; Andrews 1910; Großmann 2006; Araújo et al. 2015; Frey et al. 2017). The degree of expansion may also vary (Hawkins 1840; Andrews 1910; Großmann 2006; Druckenmiller and Russell 2008; Araújo et al. 2015; Schumacher and Martin 2015; Delsett et al. 2016; Sachs et al. 2016; Frey et al. 2017) (Fig. 6b, c, e, g). Further, it is possible that the femur and humerus have approximately the same shape or they may differ (Hawkins 1840; Großmann 2006; Schumacher and Martin 2015; Sachs et al. 2016) (e.g., Fig. 6a, e).

2013, for overall comparison to the hydrofoil flippers of sea turtles in (d) and of plesiosaurs in $(\mathbf{b}, \mathbf{c})$. b, $\mathbf{c}$ Note the hyperphalangic digits of plesiosaurs in comparison to the (partially) elongated phalanges in (d, e). Not to scale. $c$ centrale, $d c$ distal carpals, $d c 4$ distal carpal $4, d t$ distal tarsals, $h$ humerus, $f$ femur, $f i$ fibula, $f i b$ fibulare, $i$ intermedium, $p$ pisiform, $r$ radius, $r a$ radiale, $t$ tibia, $t i$ tibiale, $u$ ulna, $u l$ ulnare, $I$ digit I, $I I$ digit II, $I I I$ digit III, $I V$ digit IV, $V$ digit $\mathrm{V}$

Radius, ulna, tibia, and fibula are shortened and may diverge from the hourglass long-bone shape they have in basal Eosauropterygia (Rieppel 2000) becoming more rounded and disc-like (Andrews 1910; O'Keefe 2002; Großmann 2006; Sato et al. 2006; Druckenmiller and Russell 2008; Schumacher and Martin 2015; Sachs et al. 2016; Frey et al. 2017) (Fig. 5b, c). Often, accessory ossicles are present at the level of the zeugopodium or carpus/tarsus on the side of humerus or femur which is flared (Andrews 1910; Sato and Storrs 2000; Großmann 2006; Sato et al. 2006; Smith 2007; Druckenmiller and Russell 2008; Schumacher and Martin 2015; Sachs et al. 2016; Frey et al. 2017) (Fig. 6a-g). The fifth metacarpal and metatarsal have moved into the row of distal carpals/tarsals (Robinson 1975). The digits show hyperphalangy. Joint surfaces of the successive digits do not always lie in the same plane. The middle digit is often the longest. They become successively shorter in digit II and IV and then in I and V (Caldwell 1997, compare to e.g., Hawkins 1840; Andrews 1910; Großmann 2006; Druckenmiller and Russell 2008; Araújo et al. 2015; Schumacher and Martin 2015; Delsett et al. 2016; Sachs et al. 2016; Frey et al. 2017). All four plesiosaur limbs have evolved into hydrofoil-like flippers (Robinson 1975, 1977; Wintrich et al. 2017a). The flipper profiles were asymmetrical (Robinson 1975; Caldwell 1997; Frey et al. 2017) as those of recent underwater fliers, i.e., sea turtles and penguins (Fish 2004). 

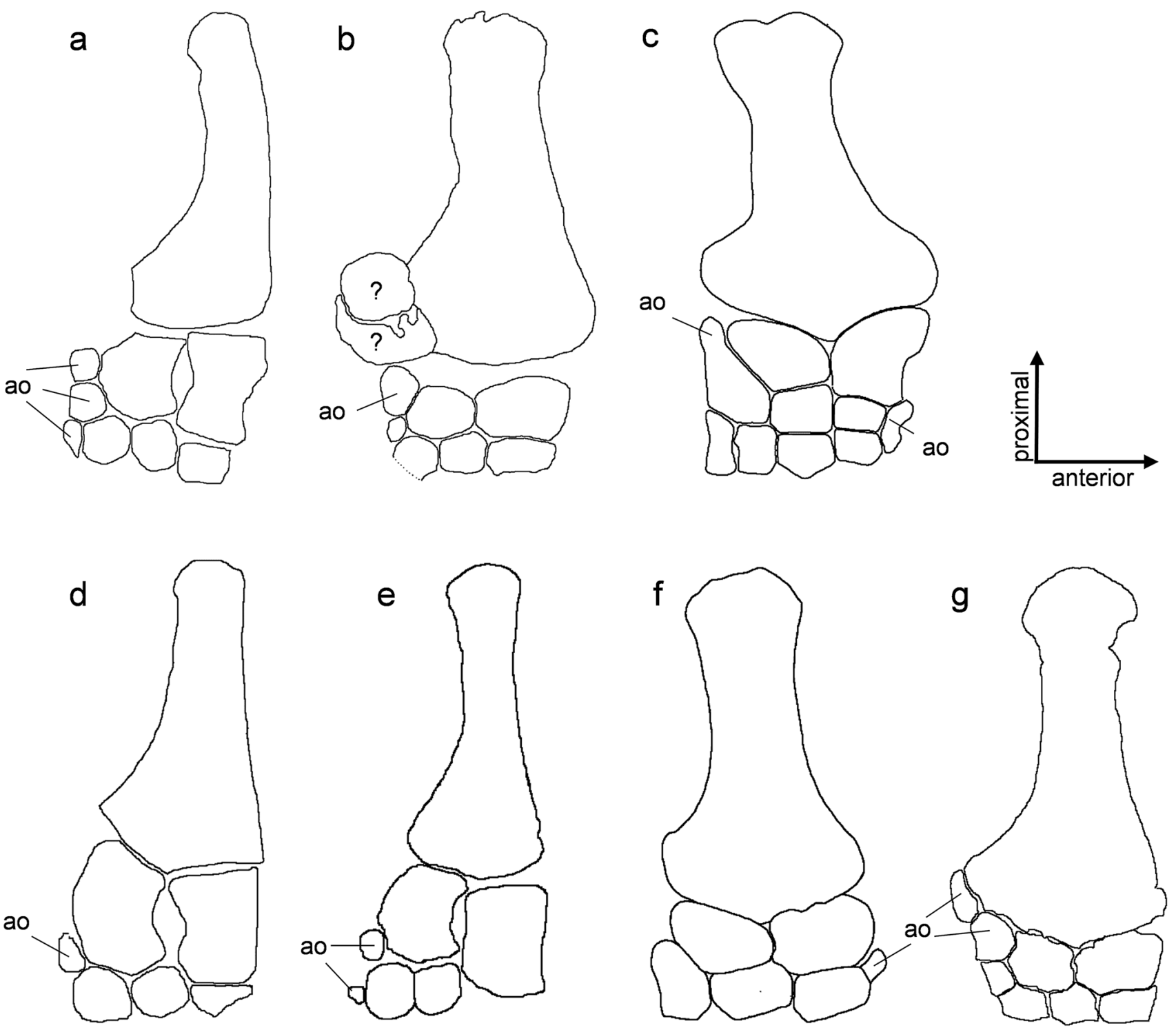

Fig. 6 Contour drawings of several humerus $(\mathbf{a}-\mathbf{c})$ and femur $(\mathbf{d}-\mathbf{g})$ shapes and the associated accessory ossicles. Long bones in (a, d) have a rather straight pre-axial margin, while the posterodistal long bones are expanded. Humerus and femur in $(\mathbf{b}, \mathbf{e})$ are slightly anterodistally and posterodistally expanded. Long bones in (c, f), and g are markedly hammer-shaped antero- and posterodistally expanded. a left foreflipper of Rhomaleosaurus victor, redrawn from Großmann (2006); b left foreflipper of Mauriciosaurus fernandezi, redrawn from Frey et al. (2017); c right foreflipper of Cryptoclidus eurymerus, redrawn from Andrews (1910); d left hindflipper of Plesiosaurus brachypterygius, redrawn from Großmann (2006); e left hindflip-

Joints - The proximal articular bony surfaces of humeri and femora of Cryptoclidus eurymerus are very incongruent with the bony glenoid and acetabular articulation surfaces. The glenoid is formed by scapula and coracoid and is oval in shape. Its long axis lies approximately in horizontal direction (Fig. 7a). The acetabulum is formed by all three hip bones (Druckenmiller and Russell 2008). It is oval in per of Rhomaleosaurus victor, redrawn from Großmann (2006); f left hindflipper of Cryptoclidus eurymerus, redrawn from Andrews (1910), mirrored; g left hindflipper of Polycotylus latipinnis, redrawn from Schumacher and Martin (2015). f Shows pre-axial and g postaxial accessory ossicle formation. The posterodistal humeral (c) and femoral (f) articulation surfaces imply that maybe a lost or poorly ossified/cartilaginous accessory ossicle was present in C. eurymerus comparably to the more proximal one of the two accessory ossicles in $P$. latipinnis $(\mathbf{g})$. Not to scale. ao accessory ossicle, ? unknown bony element

shape, but its pre-axially to post-axially axis is longer and its dorsoventral axis is shorter than in the glenoid. Posterodorsally the ilium contributes to the acetabulum and expands it posterodorsally ([personal observations on Cryptoclidus eurymerus (STIPB R 324)] (Fig. 7b). Humeral and femoral epiphyseal surfaces in Cryptoclidus eurymerus are pierced by vascular canals (Liebe and Hurum 2012; Fleischle et al. 

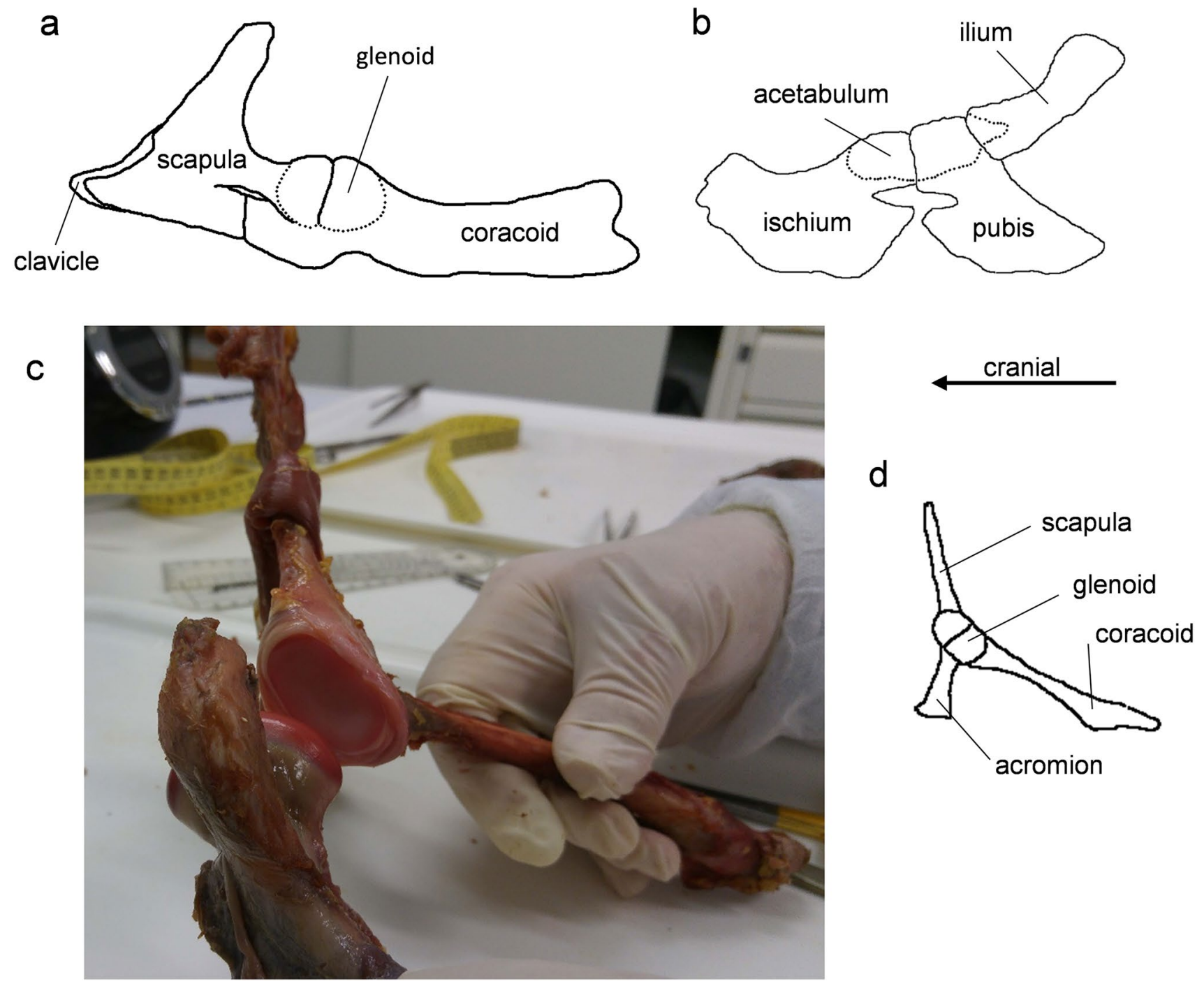

Fig. 7 Comparison of the glenoid and acetabulum of plesiosaurs with a cheloniid sea turtle. a Pectoral girdle of Cryptoclidus eurymerus, redrawn from Andrews (1910), note the oval shape of the glenoid; b pelvic girdle of Cryptoclidus eurymerus, redrawn and mirrored from Andrews (1910), the acetabulum forms a long oval shape; c pectoral girdle and humerus of a Caretta caretta after dissecting off the

2018) and show a roughened surface (personal observation) (Fig. 4g, h). The only extant species for which a comparably structured proximal humeral articulation surface is known is Dermochelys coriacea. In Dermochelys coriacea (Rhodin et al. 1981: 245, fig. 1c and Snover and Rhodin 2008: 24, fig. 2.3) the humeral articulation surface is uniquely covered by a thick, vascularized cartilage cap which is non-parallel to the underlying bone (compare to Rhodin et al. 1981: 245, fig. $1 \mathrm{~b}$ and Snover and Rhodin 2008: 24-25, fig. 2.5-2.6). This is opposed to the hyaline cartilage capping of articular surfaces of other turtles and tetrapods. Hyaline cartilage covers markedly smoother bone surfaces. It lacks vascularization and is nourished by the synovial fluid that fills the muscles, glenoid shown with intact hyaline cartilage cover (results of muscle dissection published as Krahl et al. 2019); d rough sketch of the sea turtle pectoral girdle redrawn from Wyneken (2001) for orientation. Please note how similar the rough shape of the sea turtle glenoid (c, d) resembles the plesiosaur glenoid (a), both formed by glenoid and coracoid. Drawn not to scale

joint capsule by diffusion. Thus, hyaline cartilage is only a few millimetres in thickness and, in comparison to the thick vascularized cartilage of Dermochelys coriacea, it is relatively parallel to the underlying bone surface (Rhodin et al. 1981; Snover and Rhodin 2008). Therefore, in comparison to Dermochelys coriacea, it is possible that the proximal epiphyses of plesiosaur humeri and femora were similarly capped by thick, vascularized cartilage that is not parallel to the underlying bone surface. At mid-shaft, humerus and femur are oval in transverse cross section (Krahl et al. 2013; Wintrich et al. 2017a). The elbow and carpal joints are stiffened (Storrs 1993). 

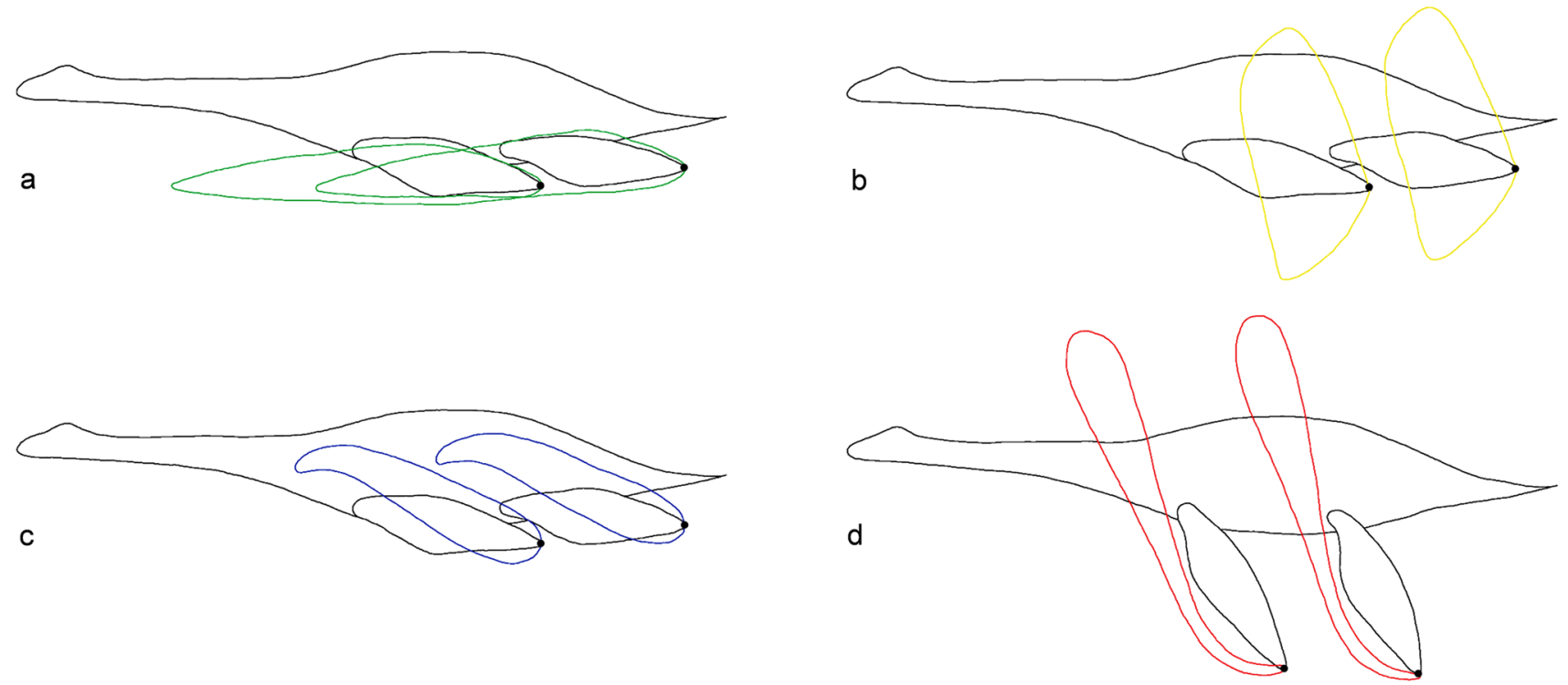

Fig. 8 Schematic drawing of a plesiosaur, based on the mounted Cryptoclidus eurymerus (STIPB R 324) skeleton on display at Goldfuß Museum, University of Bonn, Germany. Not to scale. Flipper tip excursion of one motion cycle of different groups was projected onto the plesiosaur model. a rowing in the freshwater turtle Trachemys

\section{Mode of locomotion-Proposed modes of locomotion}

Plesiosaurs are unique among recent and fossil tetrapods in that they evolved four very similarly shaped flippers. Plesiosaurs were long regarded as rowers or paddlers (Fig. 8a). In both cases, drag-based propulsion is used. By performing a rowing or paddling movement, the flipper is maximally spread and pushes against the water to propel the body forward. The recovery stroke is carried out with as little water resistance as possible (Williston 1914; Tarlo 1958). Recently, this hypothesis was reactivated again based on muscle reconstructions (Araújo and Correia 2015; Araújo et al. 2015). Rowing appears to be useful in complex habitats, in which a lot of manoeuvering, acceleration, and deceleration is necessary (Walker and Westneat 2000; Fish et al. 2003).

Godfrey (1984), Lingham-Soliar (2000), and Liu et al. (2015) suggested a further hypothesis, i.e., that plesiosaurs employed the so-called "rowing-flight" of sea lions (Otariinae) (English 1976b; Feldkamp 1987) (Fig. 8b). This locomotory mode is a combination of underwater flight and rowing elements, i.e., a combination of lift-based and dragbased propulsion. Initially the sea lion draws its foreflippers downwards (ventrally), resulting in lift and propulsion. When the maximum ventral flipper excursion is reached, the sea lion pulls its foreflippers suddenly backwards in a lateral rowing motion. When the body sinks slightly downwards, the foreflippers are passively rotated into the initial position (English 1976b; Feldkamp 1987). Liu et al. (2015)

scripta, after Rivera et al. (2013); b "rowing-flight" in the sea lion Zalophus californianus, after Feldkamp (1987); c "synchronous rowing" in the pig-nosed turtle Carettochelys insculpta, after Rivera et al. (2013); d underwater flight in the sea turtle Caretta caretta, after Rivera et al. (2013)

computationally modelled plesiosaur locomotion and find support for a rowing-flight stroke under certain circumstances, i.e., if maximum flipper excursions are presumed.

A third swimming hypothesis was proposed by Robinson $(1975,1977)$, the underwater flight, which has found the greatest endorsement so far by Lingham-Soliar (2000), Carpenter et al. (2010), Liu et al. (2015), Muscutt et al. (2017), and Krahl (2019). In contrast to rowing, in underwater flight the flipper is always moved through the water at an angle of rotation smaller than $90^{\circ}$ (Davenport et al. 1984; Walker and Westneat 2002). Because of the arched flipper profile, a net overpressure results on the underside of the profile and an underpressure on the upper side of the profile and the flipper is "sucked" and "pushed" forward at the same time by the pressure gradient (Baudinette and Gill 1985; Fish 1996; Walker and Westneat 2000). This type of locomotion is well suitable for long-distance swimmers travelling at moderate speeds (Walker and Westneat 2000).

Requiring additional discussion is the so-called "four wing problem". This is based on the unique situation that plesiosaurs have four uniformly-shaped hydrofoil flippers (Halstead 1989). The question is how the four flippers were coordinated and how the hindflippers avoid the vortex wakes of the foreflippers. Frey and Riess (1982) and Tarsitano and Riess (1982) advocate that the fore- and hindflippers were moved alternatingly, thus a continuous propulsion is ensured. That way, the hindflippers are prevented from entering the vortex wakes of the foreflipper. The recovery stroke was then supposed to have occurred passively (Frey and 
Riess 1982; Tarsitano and Riess 1982; Muscutt et al. 2017). Lingham-Soliar (2000) and Carpenter et al. (2010) endorsed the alternative hypothesis that all four flippers were moved synchronously. The plesiosaur would have moved simultaneously up- and forward, thus avoiding the danger of plunging into the vortex wakes. Long et al. (2006) carried out experiments with a swimming robot and suggested that plesiosaurs had a repertoire of different gaits, asynchronous, synchronous, semi-synchronous. These were used when needed, and they might have varied between taxa (Long et al. 2006). Based on assumptions of a variety of fore- and hindflipper motion ranges, Liu et al. (2015) show with computer simulations that the three proposed gaits are possible (see also Muscutt et al. 2017). This does not appear unlikely, because plio- and plesiosauromorph plesiosaurs have different hunting and dietary strategies (see above).

\section{Mode of locomotion-Discussion of different modes of locomotion}

In particular the stiffness of the trunk analogous to chelonioids, the shortened tail, and the long necks of the plesiosauromorph plesiosaurs, imply the necessity of evolving a paraxial mode of swimming (Storrs 1993; Lingham-Soliar 2000) but which one was employed by plesiosaurs is still controversially discussed. The enlargement of the ventral pectoral and pelvic girdle elements anterior and posterior to glenoid and acetabulum (Watson 1924; Tarlo 1958; Godfrey 1984) accompanied by the reduction of the dorsal bony elements (scapular blade and ilium) were used as arguments for rowing or a rowing element in plesiosaur locomotion (Frey and Riess 1982; Tarsitano and Riess 1982; Godfrey 1984). This is because it seems to imply relative hypertrophy of especially the locomotor muscles used in protraction and retraction originating on the coracoid and the pubis (and to a minor extent on the ventral side of the scapula and the ischium) as the respective authors argue. At the same time, this would indicate a reduction of musculature dorsal to the glenoid/acetabulum that is necessary for humeral and femoral elevation (Frey and Riess 1982; Tarsitano and Riess 1982; Godfrey 1984; Araújo and Correia 2015).

Godfrey (1984) argues that the pectoral girdle in recent underwater fliers is a strong dorsoventral support structure that suspends the forelimb to the rib cage and vertebral column and that hampers the limb's displacement during a flipper beat cycle. Contrastingly, in plesiosaurs neither the scapula nor the ilium is tightly connected to the vertebral column. Therefore, he concluded that recent penguins and sea turtles may be poor analogues for plesiosaurs. Instead, he introduced sea lions that employ rowing-flight as functional analogues (Godfrey 1984).

The concept of underwater flight in plesiosaurs (Fig. 8d) is based on the form of glenoid and acetabulum which allows mostly elevation and depression and restricts protraction and retraction (Storrs 1993). Robinson (1975) notes that plesiosaur flippers are hydrofoil-shaped, i.e., they converge distally in a pointed tip, are pre-axially thicker than post-axially, and have an arched flipper profile (Robinson 1975; Caldwell 1997). These are criteria which are not met by rowing tetrapods which have webbed and blunt-ended paddle-like feet (Robinson 1975). Sea lions and Carettochelys do not meet these characteristics either (English 1976a, 1977; Rivera et al. 2013) (Fig. 5e). The hydrofoil-shape of plesiosaur flippers seems to be corroborated by the discovery of preserved flipper soft tissue (Dames 1895; Frey et al. 2017). Flipper hydrofoils are usually utilized in underwater flight, as in Chelonioidea (see below) and Spheniscidae (Robinson 1975, 1977; LinghamSoliar 2000; Carpenter et al. 2010; Liu et al. 2015).

\section{Mode of locomotion-Carettochelys mode of locomotion}

A recent study by Rivera et al. (2013) shows that the pignosed turtle Carettochelys insculpta, a freshwater turtle, usually considered as convergent to Chelonioidea, also falls into the spectrum between rowing and underwater flight, like Otariinae. However, on the one hand, the flippers of Carettochelys move through a much larger dorsoventral excursion range than in "true" rowing turtles, but the range is significantly smaller than in Chelonioidea. On the other hand, the anteroposterior range of motion of the foreflipper is significantly greater than in sea turtles. Most of the flipper rotation needed for the rowing motion is provided by humerus rotation. Compared to sea lions, the underwater flight phase of Carettochelys occupies a much smaller percentage of the locomotory cycle (Rivera et al. 2013). Both Otariinae (Feldkamp 1987) and Carettochelys illustrate that the dichotomy of underwater flight vs. rowing might actually be considered as a continuum (Rivera et al. 2013). The flipper beat cycle of Carettochelys is discussed for the first time as a possible gait for plesiosaurs (Fig. 8c). This gait is not considered as the main swimming mode of plesiosaurs but as an option for e.g., changing direction or surfacing to breath. Further, this adds another paraxial swimming style observed in an extant taxon to the general discussion on paraxial locomotion of extinct marine Tetrapoda, that has been missing in this discussion so far.

\section{Locomotory apparatus and locomotion of Chelonioidea}

Osteology-The chelonioid trunk is stiffened by the carapace and plastron. The turtle shell is flattened and has a streamlined body outline which is hydrodynamically optimized for a life in water (Davenport et al. 1984; Dziomber et al. 2021). In aquatic (marine) and semi-aquatic (freshwater) turtles, the coracoid is expanded and enlarged and the 
scapula is reduced as compared to tortoises (Walker 1973; Wyneken 1997; Depecker et al. 2006). Thus, in freshwater and marine turtles, the dorsal musculature, which originates at the scapula, is significantly reduced, while the coracoid musculature is hypertrophied (Walker 1973). The humerus of Chelonioidea shows morphological specializations in comparison to tortoises and semi-aquatic turtles, such as a $\mathrm{v}$-shaped deltopectoral crest and a greatly enlarged medial process (Hirayama 1992; Evers and Benson 2019) implying hypertrophy of the associated muscles (Walker 1973).

The humerus is dorsoventrally flattened, and its shaft is oval in cross section (Walker 1973; Zug et al. 1986; Hirayama 1994; Wyneken 2001) (Fig. 4e). The actual flipper is formed by radius, ulna, and the manus (Walker 1973), without a contribution from the humerus. The flipper is hydrofoil-like (Walker 1973) and has an asymmetrical profile (Fish 2004). The ulna is shorter than the radius in proximodistal direction. Radius and ulna are usually levelled, but in sea turtles, the radius has been moved relatively palmar to the ulna. Chelonioids have a large pisiform, intermedium, and ulnare. Contrastingly to them, the radiale is small (Walker 1973; Evers and Benson 2019) (Fig. 5d).

Chelonioid flippers evolved by extension of the metacarpals and phalanges of the three middle digits (Shaffer et al. 1997; Richardson and Chipman 2003) (Fig. 5d). In the course of ontogeny, radius and ulna are tightly linked by connective tissue. Likewise, the digits are increasingly encased by connective tissue. Additionally, the foreflipper is covered by tough and scaly skin. Overall, this leads to a secondarily stiffened semi-rigid hydrofoil-like flipper. Contrastingly, the small, round hindflippers are not particularly stiffened or elongated (Walker 1973; Wyneken 1997), but may provide additional propulsion and are otherwise used for manoeuvering (Walker 1973; Davenport et al. 1984; Wyneken 1997).

\section{Joints}

The glenoid fossa of chelonioids is oval. Its long axis is significantly inclined in anterodorsal-posteroventral direction (compare to Wyneken 2001: 51, fig. 99, bottom right; personal observation) (Fig. 7c-d). The likewise oval humeral head (Fig. 4i) fits relatively well into the glenoid, it only appears to be slightly larger than the cavity (Walker 1973; Zug et al. 1986; Wyneken 2001; personal observation), i.e., the contact surface of humerus and glenoid is smaller than the whole humeral head. The ellipsoid shoulder joint of sea turtles allows humeral depression and elevation to a greater degree than protraction and retraction and does not allow rotation (Walker 1971; Davenport et al. 1984; Pace et al. 2001; Rivera et al. 2011). The mobile elbow functions in extension and flexion (Rivera et al. 2011). Flipper rotation appears to take place by rotation of the carpus against radius and/or ulna. The digits have only limited mobility [personal observation of a Caretta caretta specimen frozen and later thawed for a myological flipper dissection published in Krahl et al. (2019)].

\section{Mode of locomotion}

In chelonioid underwater flight, the foreflippers beat cyclically, approximating the form of a narrow skewed "O" from anterodorsal to posteroventral (Davenport et al. 1984; Rivera et al. 2011, 2013) (Fig. 8). The hypothesis of Walker (1971), who described the flipper beat cycle as an oblique figure eight was not confirmed by subsequent authors (Davenport et al. 1984; Rivera et al. 2011, 2013). Walker's (1971) description greatly influenced the work of several authors working on plesiosaur locomotion (see, e.g., Robinson 1975).

At the beginning of the downstroke, chelonioids rotate the leading edge of the foreflipper anteroventrally by rotating the carpus and manus, while during the upstroke it is rotated anterodorsally (Walker 1971). The foreflippers are thereby moved through the water at an angle of $40^{\circ}-70^{\circ}$ from the horizontal (Davenport et al. 1984). Testudines that row pull the flippers horizontally through the water (Davenport et al. 1984; Pace et al. 2001; Rivera and Blob 2010; Rivera et al. 2013). While propulsion in underwater flight is generated by both, upstroke as well as downstroke, the downstroke of Chelonioidea is observed to be more powerful than the upstroke (Walker 1971; Davenport et al. 1984; Wyneken 1997). This is in contrast to penguin underwater flight, in which up- and downstroke are equally efficient (Clark and Bemis 1979).

\section{Discussion}

Nothosaurs inhabited shallow epicontinental seas (Hagdorn et al. 1991; Hagdorn and Rieppel 1999; Rieppel 1999; Hagdorn and Simon 2005), sea turtles mostly inhabit the warmer oceans, and plesiosaurs were globally distributed. This was suggested to be due to the development of endothermy in plesiosaurs in contrast to ectothermy in sea turtles and nothosaurs (Krahl et al. 2013; Klein et al. 2016; Wintrich et al. 2017a; Fleischle et al. 2018).

Nothosaurs have a swimming tail which contributed to locomotion (Carroll and Gaskill 1985). In sea turtles the tail is much reduced, paralleled by the loss of the m. caudofemoralis portion originating from it Walker (1973). In plesiosaurs the tail is much reduced, too. Although a tail fin may be present (Smith 2013), the tail probably contributed mostly to streamlining (Frey et al. 2017).

The reduction of dorsal bones and the expansion of ventral bones of the nothosaur and plesiosaur pectoral 
and pelvic girdle (Godfrey 1984; Kuhn-Schnyder 1987) is paralleled by aquatic turtles (independent of whether they live in freshwater and row or paddle or in salt water and fly underwater) (Walker 1973; Wyneken 1997; Depecker et al. 2006). Therefore, this trend is independent of the locomotory mode employed, but instead probably connected with the reduction of the impact of gravitation on the body by buoyancy in water and due to a shift of adaptations for terrestrial locomotion to aquatic locomotion (Depecker et al. 2006). This means that the similar trend observed in Sauropterygia probably delineates convergently the transition from life on land to a life in water, but that it does not allow inferences on whether they row or fly underwater, with the knowledge of today.

Furthermore, the reduction of the dorsal bony elements and the expansion of the ventral bony elements in plesiosaurs appear to have been driven to an extreme in comparison to the state found in turtles. As pachypleurosaurs and plesiosaurs have been proven to be viviparous (Cheng et al. 2004; O'Keefe and Chiappe 2011), therefore by inference with the phylogenetic bracket, nothosaurs were giving birth to life young as well (Griebeler and Klein 2019). This indicates that Sauropterygia were completely independent from the terrestrial environment, unlike aquatic turtles, and were therefore completely freed from supporting their bodies on land. That could be the reason why sauropterygians, and especially plesiosaurs, were able to reduce the dorsal projections of the pectoral and pelvic girdle more extremely in comparison to turtles.

Nothosaur and plesiosaur flippers show increasingly hyperphalangy (for nothosaurs e.g., Storrs 1993; Rieppel 1998, for plesiosaurs e.g., Caldwell 1997, Hawkins 1840; Andrews 1910; Großmann 2006; Druckenmiller and Russell 2008; Schumacher and Martin 2015; Delsett et al. 2016; Sachs et al. 2016; Frey et al. 2017) (Fig. 5a-c). Unlike Chelonioidea, whose flippers are formed by elongation of individual phalanges of especially the three middle digits (Walker 1973) (Fig. 5d). Sea turtle and plesiosaur foreflippers taper to the flipper tip, i.e., digit III (in plesiosaurs also the hindflippers) (Walker 1973; Robinson 1975) (Fig. 5b-d). Sea turtles have an asymmetrical or cambered flipper profile which is a key characteristic for underwater-flying tetrapods (Fish 2004). Plesiosaurs might have had asymmetrical flipper profiles as well (Robinson 1975; Caldwell 1997). Contrastingly nothosaur hands are shorter and more paddle-like (Storrs 1993) and less comparable to sea turtle and plesiosaur flippers (Fig. 5a). This underscores that plesiosaur foreand hindflippers are overall convergently comparable to the hydrofoil-like foreflippers of sea turtles, but the underlying skeletal adaptations of both vary greatly (e.g., Thewissen and Taylor 2007).

The variably post-axially expanded plesiosaur humeral and femoral morphology and the possibly associated accessory ossicle formation (e.g., Andrews 1910; Sato and Storrs 2000; Großmann 2006; Sato et al. 2006; Smith 2007; Druckenmiller and Russell 2008; Schumacher and Martin 2015; Sachs et al. 2016; Frey et al. 2017) are partially accounted for in phylogenetic analyses (e.g. Benson and Druckenmiller 2014) (Fig. 6a-g). Nonetheless, they would need thorough investigations on whether this represents solely a phylogenetic, a temporal, or an ecological signal, too. It should also be checked, if the different observed patterns eventually fit into the scheme of flipper geometries determined by measuring aspect ratios by O'Keefe (2001b).

The glenoid and acetabulum of plesiosaurs greatly resemble the ellipsoid glenoids of sea turtles. Although, their long axes are differently oriented (horizontally) in plesiosaurs (personal observation, Storrs 1993) than in Chelonioidea (anterodorsally-posteroventrally) (Walker 1973; Wyneken 2001, personal observation) (Fig. 7a-d). It remains speculative what plesiosaur humeral and femoral articulation surfaces with their respective cartilaginous caps looked like (Fig. $4 \mathrm{~g}-\mathrm{h}$ ) because they were probably, convergently to Dermochelys coriacea, (Rhodin et al. 1981; Snover and Rhodin 2008) covered by thick vascularized cartilage caps and their articulation surfaces were not parallel to the underlying bone. During a foreflipper beat cycle, the sea turtle humerus is depressed and slightly retracted during the downstroke and then it is elevated and slightly protracted during the upstroke. The humerus is not rotated along its long axis at any point of the flipper beat cycle (Walker 1971; Davenport et al. 1984; Pace et al. 2001; Rivera et al. 2011). Considering the similarity between the chelonioid glenoid and the plesiosaur glenoid and acetabulum this leads to the surprising conclusion that plesiosaurs were probably unable to rotate their humeri and femora as extremely (sometimes up to $90^{\circ}$ ) as suggested by authors discussing the style of locomotion for plesiosaurs (e.g., Watson 1924; Tarlo 1958; Robinson 1975; Godfrey 1984; Lingham-Soliar 2000; Carpenter et al. 2010; Liu et al. 2015). A humerus or femur rotation by up to $90^{\circ}$ would presuppose some kind of a ball-and-socket joint that plesiosaurs certainly did not have. This leads to interesting implications: The plesiosaur glenoids/acetabula may have diverged to some degree from the sea turtle type and actually allowed some degree of humeral/femoral rotation. Alternatively, it may have been greatly underestimated and understudied how much flipper twisting along the flipper chord length (suggested briefly by Robinson 1975; Liu et al. 2015; Witzel et al. 2015) contributes to plesiosaur locomotion. A combination of both may actually have been possible. It is difficult to compare the nothosaur glenoid to either turtles or plesiosaurs because it has not been described in detail. Further, thorough investigations of joint surfaces and ranges of motion of sauropterygian limb joints could yield new insights into the evolution of paraxial swimming in Sauropterygia. 
Sea turtles have a functional elbow and wrist or intracarpal joint. The former allows simple flexion and extension of the flipper (Rivera et al. 2011, 2013) while the latter allows flipper rotation. The wrist or intracarpal joint has not been studied in detail to my knowledge. Contrastingly, the distal sea turtle flipper is much stiffened (Walker 1973). Unlike to sea turtles, the nothosaur elbow is believed to be immobile (Kuhn-Schnyder 1987). The arrangement of radius, ulna, and the carpals of the nothosaur foreflipper suggest that lower arm rotation was possible in nothosaurs like in sea turtles. Further, the nothosaur carpometacarpal and the intraphalangeal joints were probably mobile as well (personal observation). In the fore- and hindflipper of plesiosaurs, only the glenoid and acetabulum were functional joints (Storrs 1993). This needs further research, because at least the carpometacarpal/tarsometatarsal and intraphalangeal joints appear to be slightly mobile to some degree [personal observation on Cryptoclidus eurymerus (STIPB R 324)]. In sea lions intracarpal and carpometacarpal joints look as if they tightly interlock, just like in plesiosaurs. Detailed studies of the sea lion foreflipper revealed, that there is considerable variability in actual joint mobility. The mobility in each joint might appear insignificant but adds up over several joints proximodistally (English 1976a, b). In plesiosaurs, interphalangeal joint surfaces that do not align preaxially to post-axially are usually interpreted as a flipper stiffening mechanism (Caldwell 1997). Not in sea turtles, but in some cetaceans comparable non-aligned digital joints can be found e.g., in the humpback whale (Cooper et al. 2007a: 1127, fig. 3e, 1). Humpback whales have symmetrical, lift producing hydrofoils as control surfaces (Fish and Battle 1995). Their flippers bend considerably during manoeuvers and flapping (Edel and Winn 1978). Flipper bending is a well-known phenomenon across aerial and aquatic animals with flapping appendages (Lucas et al. 2014). The interdigital space appears to be larger in the less ossified cetacean foreflippers than in plesiosaur flippers (compare e.g. Cooper et al. 2007a: 1127, fig. 3e, 1 with e.g., Frey et al. 2017: 111, fig. 11). Unlike to cetaceans, plesiosaur flippers display more extreme hyperphalangy. Cooper et al. (2007b) suggest that the hyperphalangic flippers of e.g., a plesiosaur could be bend more smoothly than a flipper with longer and fewer phalanges resulting in the same amount of bending. Cooper et al. (2007b) are unsure how to interpret this functional adaptation and suggested that the smoother bending curve of the flipper might be hydrodynamically advantageous in vortex shedding. I propose that the ability to smoothly extend and flex the digits in plesiosaurs indicates flipper bending and additionally flipper twisting in plesiosaurs. Further, if the glenoid and acetabulum restricted long axis rotation to a large extent, which is given by the similarity to the sea turtle glenoid, flipper twisting would be inevitably needed for locomotion. Therefore, the issue of mobility within plesiosaur flippers would need investigation, considering the existing morphological differences between taxa. Nevertheless, the mobility of the carpometacarpal and the intraphalangeal joints of sea turtles also remains understudied. In nothosaurs, this issue has remained basically untouched. Yet, foreflipper (in plesiosaurs also hindflipper) joint mobility in all three taxa would be crucial for our understanding of paraxial locomotion in secondary aquatic tetrapods.

This article also suggested the locomotor style of Carettochelys (Rivera et al. 2013) as a possible locomotory style for plesiosaurs. Many of the osteological characteristics arguing against rowing in plesiosaurs might also argue against this type of locomotion. Yet, the flipper tip excursion path seems to fit more adequately the plesiosaur hindflipper movements that Liu et al. (2015) inferred from computer simulations (compare Fig. 8c to Liu et al. 2015: 8, fig. 4a, b) than the flipper tip excursion path described by Feldkamp (1987) for sea lions. Many osteological clues lead to the conclusion that plesiosaurs were not adapted for rowing or a combination of rowing and underwater flying as the main mode of locomotion but instead were more suited for underwater flight. Underwater flight is employed by long-distance travellers (Walker and Westneat 2000). However, it remains a possibility that nothosaurs and plesiosaurs were able to modify their locomotory style to rowing [comparable to sea turtles (Wyneken 1997)] or a rowing and flight combination [the locomotory swimming style employed by Carettochelys (Rivera et al. 2013) or otariids (Feldkamp 1987)] for changes of direction or for surfacing for breathing like sea turtles (Wyneken 1997). A gait modification by employing a combination of underwater flight and rowing might be preferrable in plesiosaurs over rowing because of their potentially limited ability to rotate the humeri and femora along their length axes.

\section{Conclusions}

While nothosaurs partially relied on tail propulsion, plesiosaurs and sea turtles exclusively rely on paraxial locomotion. The reduction of the dorsal bracing system and simultaneous increase in coracoid size in nothosaurs and plesiosaurs, often used as argument pro rowing in the past, is convergent to the secondary adaptation of aquatic turtles. In turtles, this suit of adaptations reflects the change from terrestrial to aquatic limb-based propulsion and the diminishing of the impact of gravity on the body by buoyancy. However, this suit of adaptations in turtles does not inform on the aquatic mode of locomotion (i.e., rowing, a combination of rowing and flying, or flying) they employ. Nothosaurs and plesiosaurs are not comparable to sea turtles in that the former evolved their flippers by hyperphalangy and the latter by phalangeal elongation. Superficially, sea turtles and plesiosaurs are 
comparable because both have cambered hydrofoil flippers unlike nothosaurs that evolved more paddle-like flippers. A comparison of the plesiosaur glenoid and acetabulum to the glenoid of chelonioids shows, that plesiosaurs were probably unable to rotate their flippers as much as depicted in many reconstructions of swimming plesiosaurs so far. Flipper long axis rotation might have been possible but only in a largely restricted way. Studying the joints (glenoid, acetabulum, carpometacarpal, tarsometatarsal, and interphalangeal) of plesiosaurs and nothosaurs in comparison to recent taxa could shed light on degrees of freedom and actual motion ranges which would be necessary to paint a realistic picture of plesiosaur and nothosaur locomotion on an osteological basis, including flipper rotation and flipper twisting. The mode of locomotion employed by Carettochelys insculpta is discussed for the first time as an option for plesiosaur manoeuvering. Many osteological clues point to underwater flight as the main mode of locomotion for plesiosaurs. While plesiosaur locomotion has been subject to a number of studies, nothosaur locomotion has remained largely unstudied.

Acknowledgements I would like to thank P. M. Sander, Section Paleontology, Institute of Geosciences, Rheinische Friedrich-WilhelmsUniversität Bonn, Germany for access to STIPB R 54, STIPB R324. W. Böhme, C. Koch, and D. Rödder, Zoologisches Forschungsmuseum Alexander König, Bonn, Germany for allowing me to access ZFMK 70222. F. Maffucci, Research Infrastructures for Marine Biological Resources, Stazione Zoologica Anton Dohrn Napoli, Italy and S. Hochscheid and A. Affuso, Marine Turtle Research Centre, Stazione Zoologica Anton Dohrn, Napoli Italy are greatly thanked for hosting U. Witzel and me and providing us with a Caretta specimen for dissection and their immense help and experience during the dissection. Authorization: The Caretta specimen was handled under the authorization by the Italian Ministry of Environment and Protection of the Territory and the Sea with the prot. no. 0042848/PNM del 09/08/2013. I am very thankful for many helpful comments by P. M. Sander and Prof. Dr.-Ing. $\mathrm{U}$. Witzel on earlier versions of this manuscript. The reviewers, Espen Knutsen and Yann Rollot, whose thorough comments and ideas led to a greatly improved article are thanked kindly. I am very thankful to the editors, Walter G. Joyce (Associate Editor) and Mike Reich (Editorin-Chief), for their additional remarks and their understanding of the situation of a struggling parent during the current pandemic. This work is funded by Deutsche Forschungsgemeinschafts grant WI1389/8-1.

Funding Open Access funding enabled and organized by Projekt DEAL.

Open Access This article is licensed under a Creative Commons Attribution 4.0 International License, which permits use, sharing, adaptation, distribution and reproduction in any medium or format, as long as you give appropriate credit to the original author(s) and the source, provide a link to the Creative Commons licence, and indicate if changes were made. The images or other third party material in this article are included in the article's Creative Commons licence, unless indicated otherwise in a credit line to the material. If material is not included in the article's Creative Commons licence and your intended use is not permitted by statutory regulation or exceeds the permitted use, you will need to obtain permission directly from the copyright holder. To view a copy of this licence, visit http://creativecommons.org/licenses/by/4.0/.

\section{References}

Andrews, C.W. 1910. A descriptive catalogue of the marine reptiles of the Oxford Clay, Part I. London: British Museum (Natural History).

Araújo, R., and M.J. Polcyn. 2013. A biomechanical analysis of the skull and adductor chamber muscles in the Late Cretaceous plesiosaur Libonectes. Palaeontologia Electronica 16(2): 1-25.

Araújo, R., and F. Correia. 2015. Soft-tissue anatomy of the plesiosaur pectoral girdle inferred from basal Eosauropterygia taxa and the extant phylogenetic bracket. Palaeontologica Electronica 18(1): $1-32$.

Araújo, R., M.J. Polcyn, A.S. Schulp, O. Mateus, L.L. Jacobs, A.O. Gonçalves, and M.-L. Morais. 2015. A new elasmosaurid from the early Maastrichtian of Angola and the implications of girdle morphology on swimming style in plesiosaurs. Netherlands Journal of Geosciences/Geologie en Mijnbouw 94(1): 109-120.

Baier, D.B., S.M. Gatesy, and F.A. Jenkins Jr. 2007. A critical ligamentous mechanism in the evolution of avian flight. Nature 445: 307-310. https://doi.org/10.1038/nature05435.

Bardet, N. 1994. Extinction events among Mesozoic marine reptiles. Historical Biology 7(4): 313-324.

Bardet, N., J. Falconnet, V. Fischer, A. Houssaye, S. Jouve, X. Pereda Suberbiola, A. Pérez-García, J.-C. Rage, and P. Vincent. 2014. Mesozoic marine reptile palaeobiogeography in response to drifting plates. Gondwana Research 26(3-4): 869-887.

Baudinette, R.V., and P. Gill. 1985. The energetics of 'flying' and 'paddling' in water: Locomotion in penguins and ducks. Journal of Comparative Physiology B 155(3): 373-380.

Beche, H.T. de la, and W.D. Conybeare. 1821. Notice of the discovery of a new fossil animal, forming a link between the Ichthyosaurus and crocodile, together with general remarks on the osteology of the ichthyosaurs. Transactions of the Geological Society of London (series 1) 5: 559-594.

Benson, R.B.J., and P.S. Druckenmiller. 2014. Faunal turnover of marine tetrapods during the Jurassic-Cretaceous transition. Biological Reviews 89: 1-23.

Benson, R.B.J., M. Evans, and P.S. Druckenmiller. 2012. High diversity, low disparity and small body size in plesiosaurs (Reptilia, Sauropterygia) from the Triassic-Jurassic boundary. PLOS ONE 7(3): e31838. https://doi.org/10.1371/journal.pone.0031838.

Bickelmann, C., and P.M. Sander. 2008. A partial skeleton and isolated humeri of Nothosaurus (Reptilia: Eosauropterygia) from Winterswijk, The Netherlands. Journal of Vertebrate Paleontology 28(2): 326-338.

Brown, D.S. 1981. The English Upper Jurassic Plesiosauroidea (Reptilia) and a review of the phylogeny and classification of the Plesiosauria. Bulletin of the British Museum of Natural History (Geology) 35: 253-347.

Buchy, M.-C., E. Frey, and S. Salisbury. 2006. The internal cranial anatomy of the Plesiosauria (Reptilia, Sauropterygia): Evidence for a functional secondary palate. Lethaia 39(4): 289-303.

Caldwell, M.W. 1997. Limb osteology and ossification patterns in Cryptoclidus (Reptilia: Plesiosauroidea) with a review of Sauropterygian limbs. Journal of Vertebrate Paleontology 17(2): 295-307.

Carpenter, K., F. Sanders, B. Reed, J. Reed, and P. Larson. 2010. Plesiosaur swimming as interpreted from skeletal analysis and experimental results. Transactions of the Kansas Academy of Science $113(1 / 2)$ : $1-34$

Carr, A.F. 1952. Handbook of turtles. The turtles of the United States, Canada and Baja California. Ithaca, N.Y.: Cornell University Press. 
Carroll, R.L. 2013. Problems of the ancestry of turtles. In Morphology and evolution of turtles, eds. D.B. Brinkman, P.A. Holroyd, and J.D. Gardner, 19-36. Dordrecht: Springer.

Carroll, R.L., and P. Gaskill. 1985. The nothosaur Pachypleurosaurus and the origin of plesiosaurs. Proceedings of the Royal Society (B: Biological Sciences) 309(1139): 343-393.

Chaves, C.M. de, S. García-Gil, F. Ortega, J.L. Sanz, and A. PérezGarcía. 2016. First Triassic tetrapod (Sauropterygia, Nothosauridae) from Castilla y León: evidence of an unknown taxon for the Spanish record. Journal of Iberian Geology 42(1): 29-38.

Chaves, C.M. de, C., F. Ortega, and A. Pérez-García. 2018. New highly pachyostotic nothosauroid interpreted as a filter-feeding Triassic marine reptile. Biology Letters 14(8): 20180130. https://doi.org/10.1098/rsbl.2018.0130.

Cheng, Y.-N., X.-C. Wu, and Q. Ji. 2004. Triassic marine reptiles gave birth to live young. Nature 432: 383-386.

Cheng, Y.-N., X.-C. Wu, T. Sato, and H.-Y. Sun. 2016. Dawazisaurus brevis, a new Eosauropterygian from the Middle Triassic of Yunnan. China. Acta Geologica Sinica (english Edition) 90(2): 401-424.

Cicimurri, D.J., and M.J. Everhart. 2001. An elasmosaur with stomach contents and gastroliths from the Pierre Shale (Late Cretaceous) of Kansas. Transactions of the Kansas Academy of Science 104(3/4): 129-143.

Clark, B.D., and W. Bemis. 1979. Kinematics of swimming of penguins at the Detroit Zoo. Journal of Zoology 188(3): 411-428.

Cooper, L.N., S.D. Dawson, J.S. Reidenberg, and A. Berta. 2007a. Neuromuscular anatomy and evolution of the cetacean forelimb. The Anatomical Record 290: 1121-1137.

Cooper, L.N., A. Berta, S.D. Dawson, and J.S. Reidenberg. 2007b. Evolution of hyperphalangy and digit reduction in the cetacean manus. The Anatomical Record 290: 654-672.

Crawford, N.G., J.F. Parham, A.B. Sellas, B.C. Faircloth, T.C. Glenn, T.J. Papenfuss, J.B. Henderson, M.H. Hansen, and W.B. Simison. 2015. A phylogenomic analysis of turtles. Molecular Phylogenetics and Evolution 83: 250-257.

Cruickshank, A.R.I., P.G. Small, and M.A. Taylor. 1991. Dorsal nostrils and hydrodynamically driven underwater olfaction in plesiosaurs. Nature 352(6330): 62-64.

Dames, H.W. 1895. Die Plesiosaurier der süddeutschen Liasformation. Physikalische und Mathematische Abhandlungen der Königlichen Preussischen Akademie der Wissenschaften zu Berlin 2: $1-83$.

Davenport, J., S.A. Munks, and P.J. Oxford. 1984. A comparison of the swimming of marine and freshwater turtles. Proceedings of the Royal Society (B: Biological Sciences) 220(1221): 447-475.

Davenport, J., T.T. Jones, T.M. Work, and G.H. Balazs. 2015. Topsyturvy: turning the counter-current heat exchange of leatherback turtles upside down. Biology Letters 11(10): 20150592. https:// doi.org/10.1098/rsbl.2015.0592.

Delsett, L.L., L.K. Novis, A.J. Roberts, M.J. Koevoets, Ø. Hammer, P.S. Druckenmiller, and J.H. Hurum. 2016. The Slottsmøya marine reptile Lagerstätte: depositional environments, taphonomy and diagenesis. Geological Society of London, Special Publications 434(1): 165-188.

Depecker, M., C. Berge, X. Penin, and S. Renous. 2006. Geometric morphometrics of the shoulder girdle in extant turtles (Chelonii). Journal of Anatomy 208(1): 35-45.

Druckenmiller, P.S., and A.P. Russell. 2008. A phylogeny of Plesiosauria (Sauropterygia) and its bearing on the systematic status of Leptocleidus Andrews, 1922. Zootaxa 1863: 1-120.

Dziomber, L., W.G. Joyce, and C. Foth. 2021. The ecomorphology of the shell of extant turtles and its applications for fossil turtles. PeerJ 8: e10490. https://doi.org/10.7717/peerj.10490.
Edel, R.K., and H.E. Winn. 1978. Observations on underwater locomotion and flipper movement of the humpback whale $\mathrm{Meg}$ aptera novaeangliae. Marine Biology 48(3): 279-287.

English, A.M. 1976a. Functional anatomy of the hands of fur seals and sea lions. The American Journal of Anatomy 147(1): 1-18.

English, A.W. 1976b. Limb movements and locomotor function in the California sea lion. Journal of Zoology 178: 341-364.

English, A.W.M. 1977. Structural correlates of forelimb function in fur seals and sea lions. Journal of Morphology 151(3): $325-352$.

Evers, S.W., and R.B.J. Benson. 2019. A new phylogenetic hypothesis of turtles with implications for the timing and number of evolutionary transitions to marine lifestyles in the group. Palaeontology 62(1): 93-134.

Fabbri, M., F.M. Dalla Vecchia, and A. Cau. 2013. New information on Bobosaurus forojuliensis (Reptilia: Sauropterygia): Implications for plesiosaurian evolution. Historical Biology 26(5): 661-669.

Feldkamp, S.D. 1987. Foreflipper propulsion in the California sea lion, Zalophus californianus. Journal of Zoology 212: 43-57.

Field, D.J., J.A. Gauthier, B.L. King, D. Pisani, T.R. Lyson, and K.J. Peterson. 2014. Toward consilience in reptile phylogeny: miRNA support an archosaur, not lepidosaur, affinity for turtles. Evolution and Development 16(4): 189-196.

Fish, F.E. 1996. Transitions from drag-based to lift-based propulsion in mammalian swimming. American Zoologist 36(6): 628-641. https://doi.org/10.1093/icb/36.6.628.

Fish, F.E. 2004. Structure and mechanics of nonpiscine control surfaces. IEEE Journal of Oceanic Engineering 29(3): 605-621.

Fish, F.E., and J.M. Battle. 1995. Hydrodynamic design of the humpback whale flipper. Journal of Morphology 225(1): 51-60.

Fish, F.E., J. Hurley, and D.P. Costa. 2003. Maneuverability by the sea lion Zalophus californianus: Turning performance of an unstable body design. Journal of Experimental Biology 206: 667-674.

Fleischle, C.V., T. Wintrich, and P.M. Sander. 2018. Quantitative histological models suggest endothermy in plesiosaurs. PeerJ 6: e4955. https://doi.org/10.7717/peerj.4955.

Foffa, D., J. Sassoon, A.R. Cuff, M.N. Mavrogordato, and M.J. Benton. 2014a. Complex rostral neurovascular system in a giant pliosaur. Die Naturwissenschaften 101(5): 453-456.

Foffa, D., A.R. Cuff, J. Sassoon, E.J. Rayfield, M.N. Mavrogordato, and M.J. Benton. 2014b. Functional anatomy and feeding biomechanics of a giant Upper Jurassic pliosaur (Reptilia: Sauropterygia) from Weymouth Bay, Dorset UK. Journal of Anatomy 225(2): 209-219.

Frey, E., and J. Riess. 1982. Considerations concerning plesiosaur locomotion. Neues Jahrbuch für Geologie und Paläontologie, Abhandlungen 164: 193-194.

Frey, E., E.W.A. Mulder, W. Stinnesbeck, H.E. Rivera-Sylva, J.M. Padilla-Gutiérrez, and A.H. González-González. 2017. A new polycotylid plesiosaur with extensive soft tissue preservation from the early Late Cretaceous of northeast Mexico. Boletín de la Sociedad Geológica Mexicana 69(1): 87-134.

Frick, M.G., K.L. Williams, A.B. Bolten, K.A. Bjorndal, and H.R. Martins. 2009. Foraging ecology of oceanic-stage loggerhead turtles Caretta caretta. Endangered Species Research 9: 91-97.

Godfrey, S.J. 1984. Plesiosaur subaqueous locomotion: a reappraisal. Neues Jahrbuch für Geologie und Paläontologie, Monatshefte 1984(11): 661-672.

Griebeler, E.M., and N. Klein. 2019. Life-history strategies indicate live-bearing in Nothosaurus (Sauropterygia). Palaeontology 62(4): 697-713. https://doi.org/10.1111/pala.12425.

Großmann, F. 2006. Taxonomy, phylogeny and palaeoecology of the plesiosauroids (Sauropterygia, Reptilia) from the Posidonia 
shale (Toarcian, Lower Jurassic) of Holzmaden, south West Germany. Dissertation, Eberhard-Karls-Universität, Tübingen.

Hagdorn, H., and O. Rieppel. 1999. Stratigraphy of marine reptiles in the Triassic of Central Europe. Zentralblatt für Geologie und Paläontologie (Teil I) 1999(1): 651-678.

Hagdorn, H., and T. Simon. 2005. Der Muschelkalk in der Stratigraphischen Tabelle von Deutschland 2002. Newsletter on Stratigraphy 41: 143-158.

Hagdorn, H., T. Simon, and J. Szulc. 1991. Muschelkalk: A field guide. Stuttgart/Korb: Goldschneck-Verlag/W.K. Weidert.

Halstead, L.B. 1989. Plesiosaur locomotion. Journal of the Geological Society 146(1): 37-40.

Hawkins, T.H. 1840. The Book of the Great Sea-Dragons, Ichthyosauri and Plesiosauri, Gedolim Taninim, of Moses: Extinct monsters of the ancient earth. London: W. Pickering.

Hill, R.V. 2005. Integration of morphological data sets for phylogenetic analysis of Amniota: The importance of integumentary characters and increased taxonomic sampling. Systematic Biology 54(4): 530-547.

Hirayama, R. 1992. Humeral morphology of chelonioid sea turtles: its functional analysis and phylogenetic implications. Bulletin of the Hobetsu Museum 8: 17-57.

Hirayama, R. 1994. Phylogenetic systematics of chelonioid sea turtles. The Island Arc 3: 270-284.

Hirayama, R. 1998. Oldest known sea turtle. Nature 392(6677): 705-708.

Holmes, R., Y.-N. Cheng, and X.-C. Wu. 2008. New information on the skull of Keichousaurus hui (Reptilia: Sauropterygia) with comments on sauropterygian interrelationships. Journal of Vertebrate Paleontology 28(1): 76-84.

Houssaye, A., P. Tafforeau, C. de Muizon, and P.D. Gingerich. 2015. Transition of Eocene whales from land to sea. Evidence from bone microstructure. PLOS ONE 10(2): e0118409. https://doi. org/10.1371/journal.pone.0118409.

Hugi, J. 2011. The long bone histology of Ceresiosaurus (Sauropterygia, Reptilia) in comparison to other eosauropterygians from the Middle Triassic of Monte San Giorgio (Switzerland/ Italy). Swiss Journal of Palaeontology 130(2): 297-306.

Iwabe, N., Y. Hara, Y. Kumazawa, K. Shibamoto, Y. Saito, T. Miyata, and K. Katoh. 2005. Sister group relationship of turtles to the bird-crocodilian clade revealed by nuclear DNA-coded proteins. Molecular Biology and Evolution 22(4): 810-813.

Jiang, D.-Y., R. Motani, A. Tintori, O. Rieppel, G.-B. Chen, J.-D. Huang, R. Zhang, Z.-Y. Sun, and C. Ji. 2014. The Early Triassic eosauropterygian Majiashanosaurus discocoracoidis, gen. et sp. nov. (Reptilia, Sauropterygia), from Chaohu, Anhui Province, People's Republic of China. Journal of Vertebrate Paleontology 34(5): 1044-1052.

Kear, B.P., N.I. Schroeder, and M.S. Lee. 2006. An archaic crested plesiosaur in opal from the Lower Cretaceous high-latitude deposits of Australia. Biology Letters 2(4): 615-619.

Ketchum, H.F., and R.B.J. Benson. 2010. Global interrelationships of Plesiosauria (Reptilia, Sauropterygia) and the pivotal role of taxon sampling in determining the outcome of phylogenetic analyses. Biological Reviews 85(2): 361-392.

Klein, N. 2010. Long bone histology of Sauropterygia from the lower Muschelkalk of the Germanic basin provides unexpected implications for phylogeny. PLOS ONE 5(7): e11613. https://doi.org/ 10.1371/journal.pone.0011613.

Klein, N., D.F.A.E. Voeten, J. Lankamp, R. Bleeker, O.J. Sichelschmidt, M. Liebrand, D. Nieweg, and P.M. Sander. 2015. Postcranial material of Nothosaurus marchicus from the Lower Muschelkalk (Anisian) of Winterswijk, The Netherlands, with remarks on swimming styles and taphonomy. PalZ. Paläontologische Zeitschrift 89: 961-981. https://doi.org/10.1007/ s12542-015-0273-5.
Klein, N., P.M. Sander, A. Krahl, T.M. Scheyer, and A. Houssaye. 2016. Diverse aquatic adaptations in Nothosaurus spp. (Sauropterygia): inferences from humeral histology and microanatomy. PLoS ONE 11(7): e0158448. https://doi.org/10.1371/ journal.pone. 0158448 .

Krahl, A. 2019. Underwater flight in sea turtles and plesiosaurs: Dissection, muscle reconstructions, analog models, and finite element structure analyses inform on flipper twisting and muscle forces in plesiosaurs, 1-311. Dissertation, MathematischNaturwissenschaftliche Fakultät der Rheinischen FriedrichWilhelms-Universität Bonn. https://nbn-resolving.org/urn: nbn:de:hbz:5-59143.

Krahl, A., N. Klein, and P.M. Sander. 2013. Evolutionary implications of the divergent long bone histologies of Nothosaurus and Pistosaurus (Sauropterygia, Triassic). BMC Evolutionary Biology 13(1): 123. https://doi.org/10.1186/1471-2148-13-123.

Krahl, A., A. Lipphaus, U. Witzel, P.M. Sander, F. Maffucci, and S. Hochscheid. 2019. Humerus osteology, myology, and finite element structure analysis of Cheloniidae. The Anatomical Record 303(8): 2177-2191. https://doi.org/10.1002/ar.24311).

Kuhn-Schnyder, E. 1987. Die Triasfauna der Tessiner Kalkalpen. XXVI. Lariosaurus lavizzarii n. sp. (Reptilia, Sauropterygia). Schweizerische Paläontologische Abhandlungen 110: 1-24.

Liebe, L., and H. Hurum. 2012. Gross internal structure and microstructure of plesiosaur limb bones from the Late Jurassic, central Spitsbergen. Norwegian Journal of Geology 92: 285-309.

Limpus, C.J., J.D. Miller, C.J. Parmenter, D. Reimer, N. McLachland, and R. Webb. 1992. Migration of green (Chelonia mydas) and loggerhead (Caretta caretta) turtles to and from eastern Australian rookeries. Wildlife Research 19: 347-358.

Lin, W.-B., D.-Y. Jiang, O. Rieppel, R. Motani, C. Ji, A. Tintori, Z.-Y. Sun, and M. Zhou. 2017. A new specimen of Lariosaurus xingyiensis (Reptilia, Sauropterygia) from the Ladinian (Middle Triassic) Zhuganpo Member, Falang Formation, Guizhou. China. Journal of Vertebrate Paleontology 37(2): e1278703. https://doi.org/10.1080/02724634.2017.1278703.

Lingham-Soliar, T. 2000. Plesiosaur locomotion: Is the four-wing problem real or merely an atheoretical exercise? Neues Jahrbuch für Geologie und Paläontologie, Abhandlungen 217(1): 45-87.

Liu, J., S.-X.H.O. Rieppel, D.-Y. Jiang, M.J. Benton, N.P. Kelley, J.C. Aitchison, C.-Y.Z.W. Wen, H. Jin-Yuan, X. Tao, and T. Lv. 2014. A gigantic nothosaur (Reptilia: Sauropterygia) from the Middle Triassic of SW China and its implication for the Triassic biotic recovery. Scientific Reports 4: 7142. https://doi.org/10.1038/ srep07142.

Liu, S., A.S. Smith, Y. Gu, J. Tan, C.K. Liu, and G. Turk. 2015. Computer simulations imply forelimb-dominated underwater flight in plesiosaurs. PLoS Computational Biology 11(12): e1004605. https://doi.org/10.1371/journal.pcbi.1004605.

Long, J.H., J. Schumacher, N. Livingston, and M. Kemp. 2006. Four flippers or two?: Tetrapodal swimming with an aquatic robot. Bioinspiration \& Biomimetics 1(1): 20-29.

Lucas, K.N., N. Johnson, W.T. Beaulieu, E. Cathcart, G. Tirrell, S.P. Colin, B.J. Gemmell, J.O. Dabiri, and J.H. Costello. 2014. Bending rules for animal propulsion. Nature Communications 5: 3293. https://doi.org/10.1038/ncomms4293.

Lyson, T.R., and G.S. Bever. 2020. Origin and evolution of the turtle body plan. Annual Reviews of Ecology, Evolution, and Systematics 51: 143-166.

Lyson, T.R., G.S. Bever, B.-A.S. Bhullar, W.G. Joyce, and J.A. Gauthier. 2010. Transitional fossils and the origin of turtles. Biology Letters 6: 830-833.

Lyson, T.R., E.A. Sperling, A.M. Heimberg, J.A. Gauthier, B.L. King, and K.J. Peterson. 2012. MicroRNAs support a turtle + lizard clade. Biology Letters 8(1): 104-107. 
Massare, J.A. 1988. Swimming capabilities of Mesozoic marine reptiles: Implications for method of predation. Paleobiology 14(2): 187-205.

McHenry, C.R., A.G. Cook, and S. Wroe. 2005. Bottom-feeding plesiosaurs. Science 310(5745): 75. https://doi.org/10.1126/scien ce. 1117241.

Merck, J.W. 1997. A phylogenetic analysis of the euryapsid reptiles. Journal of Vertebrate Paleontology 17: 65.

Meyer von, H. 1847-1855. Zur Fauna der Vorwelt. Die Saurier des Muschelkalkes mit Rücksicht auf die Saurier aus buntem Sandstein und Keuper. Frankfurt am Main: H. Keller.

Meylan, A. 1982. Sea turtle migration-evidence from tag returns. In Biology and conservation of sea turtles, ed. K.A. Björndal, 91-100. Washington, D.C.: Smithsonian Institution Press.

Motani, R. 2009. The evolution of marine reptiles. Evolution: Education and Outreach 2(2): 224-235.

Motani, R., D.-Y. Jiang, O. Rieppel, Y.-F. Xue, and A. Tintori. 2015. Adult sex ratio, sexual dimorphism and sexual selection in a Mesozoic reptile. Proceedings of the Royal Society (B: Biological Sciences) 282(1815): 20151658. https://doi.org/10.1098/rspb. 2015.1658.

Muscutt, L.E., G. Dyke, G.D. Weymouth, D. Naish, C. Palmer, and B. Ganapathisubramani. 2017. The four-flipper swimming method of plesiosaurs enabled efficient and effective locomotion. Proceedings of the Royal Society (B: Biological Sciences) 284(1861): 20170951. https://doi.org/10.1098/rspb.2017.0951.

Nagesan, R.S., D.M. Henderson, and J.S. Anderson. 2018. A method for deducing neck mobility in plesiosaurs, using the exceptionally preserved Nichollssaura borealis. Royal Society Open Science 5(8): 172307. https://doi.org/10.1098/rsos.172307.

Naro-Maciel, E., M. Le, N.N. Fitzsimmons, and G. Amato. 2008. Evolutionary relationships of marine turtles: A molecular phylogeny based on nuclear and mitochondrial genes. Molecular Phylogenetics and Evolution 49(2): 659-662.

Neenan, J.M., N. Klein, and T.M. Scheyer. 2013. European origin of placodont marine reptiles and the evolution of crushing dentition in Placodontia. Nature Communications 4: 1621. https://doi.org/ 10.1038/ncomms2633.

Neenan, J.M., C. Li, O. Rieppel, and T.M. Scheyer. 2015. The cranial anatomy of Chinese placodonts and the phylogeny of Placodontia (Diapsida: Sauropterygia). Zoological Journal of the Linnean Society 175(2): 415-428.

Neenan, J.M., T. Reich, S.W. Evers, P.S. Druckenmiller, D.F.A.E. Voeten, J.N. Choiniere, P.M. Barrett, S.E. Pierce, and R.B.J. Benson. 2017. Evolution of the sauropterygian labyrinth with increasingly pelagic lifestyles. Current Biology 27(24): 38523858.e3. https://doi.org/10.1016/j.cub.2017.10.069.

O`Gorman, J.P., L. Salgado, I.A. Cerda, and Z. Gasparini. 2013. First record of gastroliths associated with elasmosaur remains from La Colonia Formation (Campanian-Maastrichtian), Chubut, Patagonia Argentina, with comments on the probable depositional palaeoenvironment of the source of the gastroliths. Cretaceous Research 40: 212-217.

O`Gorman, J.P., E.B. Olivero, S. Santillana, M.J. Everhart, and R. Reguero. 2014. Gastroliths associated with an Aristonectes specimen (Plesiosauria, Elasmosauridae), López de Bertodano Formation (upper Maastrichtian) Seymour Island (Is. Marambio), Antarctic Peninsula. Cretaceous Research 50: 228-237.

O'Keefe, F.R. 2001a. A cladistic analysis and taxonomic revision of the Plesiosauria (Reptilia: Sauropterygia). Acta Zoologica Fennica 213: 1-63.

O'Keefe, F.R. 2001b. Ecomorphology of plesiosaur flipper geometry. Journal of Evolutionary Biology 14(6): 987-991.

O'Keefe, F.R. 2002. The evolution of plesiosaur and pliosaur morphotypes in the Plesiosauria (Reptilia: Sauropterygia). Paleobiology 28(1): 101-112.
O'KeefeCarrano, F.R.M.T. 2005. Correlated trends in the evolution of the plesiosaur locomotor system. Paleobiology 31(4): 656-675.

O'KeefeChiappe, F.R.L.M. 2011. Viviparity and k-selected life history in a Mesozoic marine plesiosaur (Reptilia, Sauropterygia). Science 333(6044): 870-873.

O 'KeefeOteroSoto-AcuñaO 'GormanGodfreyChatterjee, F.R.R.A.S.J.P.S.J.S. 2017. Cranial anatomy of Morturneria seymourensis from Antarctica, and the evolution of filter feeding in plesiosaurs of the Austral Late Cretaceous. Journal of Vertebrate Paleontology 37(4): e1347570. https://doi.org/10.1080/02724 634.2017.1347570.

Owen, R. 1840. Report on British fossil reptiles. Report of the Nineth Meeting of the British Association for the Advancement of Science 9: 43-126.

Pace, C.M., R.W. Blob, and M.W. Westneat. 2001. Comparative kinematics of the forelimb during swimming in red-eared slider (Trachemys scripta) and spiny softshell (Apalone spinifera) turtles. The Journal of Experimental Biology 204: 3261-3271.

Pereira, A.G., J. Sterli, F.R.R. Moreira, and C.G. Schrago. 2017. Multilocus phylogeny and statistical biogeography clarify the evolutionary history of major lineages of turtles. Molecular Phylogenetics and Evolution 113: 59-66.

Renesto, S. 1993. A juvenile Lariosaurus (Reptilia, Sauropterygia) from the Kalkschieferzone (Uppermost Ladinian) near Viggiu (Varese, Northern Italy). Rivista Italiana di Paleontologia e Stratigrafia 99: 199-212.

Rhodin, A.G.J., J.A. Ogden, and G.J. Conlogue. 1981. Chondro-osseous morphology of Dermochelys coricacea, a marine reptile with mammalian skeletal features. Nature 290: 244.

Richardson, M.K., and A.D. Chipman. 2003. Developmental constraints in a comparative framework: a test case using variations in phalanx number during amniote evolution. Journal of Experimental Zoology 296B: 8-22.

Rieppel, O. 1995. The genus Placodus: Systematics, morphology, paleobiogeography, and paleobiology. Fieldiana Geology 31: 1-44.

Rieppel, O. 1997. Sauropterygia from the Muschelkalk of Djebel Rehach, southern Tunisia. Neues Jahrbuch für Geologie und Paläontologie, Monatshefte 1997(9): 517-530.

Rieppel, O. 1998. The status of the sauropterygian reptile genera $\mathrm{Cer}$ esiosaurus, Lariosaurus, and Silvestrosaurus from the Middle Triassic of Europe. Fieldiana Geology 38: 1-46.

Rieppel, O. 1999. Phylogeny and paleobiogeography of Triassic Sauropterygia: Problems solved and unresolved. Palaeogeography, Palaeoclimatology, Palaeoecology 153(1-4): 1-15.

Rieppel, O. 2000. Sauropterygia I: Placodontia, Pachypleurosauria, Nothosauroidea, Pistosauroidea. In Encyclopedia of Paleoherpetology No. 12A, ed. P. Wellnhofer, 1-134. Munich: F. Pfeil.

Rieppel, O. 2002. Feeding mechanics in Triassic stem-group sauropterygians: The anatomy of a successful invasion of Mesozoic seas. Zoological Journal of the Linnean Society 135(1): 33-63.

Rieppel, O., and R.R. Reisz. 1999. The origin and early evolution of turtles. Annual Review of Ecology and Systematics 30: 1-22.

Rieppel, O., J.-M. Mazin, and E. Tchernov. 1997. Speciation along rifting continental margins: a new nothosaur from the Negev (Israel). Comptes rendus de l'Académie des Sciences, Paris 325: 991-997.

Rivera, A.R.V., and R.W. Blob. 2010. Forelimb kinematics and motor patterns of the slider turtle (Trachemys scripta) during swimming and walking: Shared and novel strategies for meeting locomotor demands of water and land. The Journal of Experimental Biology 213(20): 3515-3526.

Rivera, A.R.V., J. Wyneken, and R.W. Blob. 2011. Forelimb kinematics and motor patterns of swimming loggerhead sea turtles (Caretta caretta): Are motor patterns conserved in the evolution of new 
locomotor strategies? The Journal of Experimental Biology 214(19): 3314-3323.

Rivera, A.R.V., G. Rivera, and R.W. Blob. 2013. Forelimb kinematics during swimming in the pig-nosed turtle, Carettochelys insculpta, compared with other turtle taxa: Rowing versus flapping, convergence versus intermediacy. The Journal of Experimental Biology 216(4): 668-680.

Robinson, J.A. 1975. The locomotion of plesiosaurs. Neues Jahrbuch Geologie Und Paläontologie, Abhandlungen 149: 286-332.

Robinson, J.A. 1977. Intracorporal force transmission in plesiosaurs. Neues Jahrbuch Geologie Paläontologie, Abhandlungen 153: 86-128.

Romer, A.S. 1976. Osteology of the reptiles, 3rd ed. Chicago, Ill.: University of Chicago Press.

Sachs, S., J.J. Hornung, and B.P. Kear. 2016. Reappraisal of Europe's most complete early Cretaceous plesiosaurian: Brancasaurus brancai Wegner, 1914 from the "Wealden facies" of Germany. PeerJ 4: e2813. https://doi.org/10.7717/peerj.2813.

Sander, P.M. 1989. The pachypleurosaurids (Reptilia: Nothosauria) from the Middle Triassic of Monte San Giorgio, (Switzerland), with the description of a new species. Philosophical Transactions of the Royal Society of London (B: Biological Sciences) 325: 561-670.

Sato, T., and G.W. Storrs. 2000. An early polycotylid plesiosaur (Reptilia: Sauropterygia) from the Cretaceous of Hokkaido, Japan. Journal of Paleontology 74(5): 907-914.

Sato, T., and K. Tanabe. 1998. Cretaceous plesiosaurs ate ammonites. Nature 394(6694): 629-630.

Sato, T., Y. Hasegawa, and M. Manabe. 2006. A new elasmosaurid plesiosaur from the Upper Cretaceous of Fukushima, Japan. Palaeontology 49(3): 467-484.

Schmeisser, R.L., and D.D. Gillette. 2009. Unusual occurrence of gastroliths in a polycotylid plesiosaur from the Upper Cretaceous Tropic Shale, southern Utah. Palaios 24(7): 453-459.

Schoch, R.R., and H.-D. Sues. 2015. A Middle Triassic stem-turtle and the evolution of the turtle body plan. Nature 523(7562): 584-587.

Schumacher, B.A., and J.E. Martin. 2015. Polycotylus latipinnis Cope (Plesiosauria, Polycotylidae), a nearly complete skeleton from the Niobrara Formation (early Campanian) of southwestern South Dakota. Journal of Vertebrate Paleontology 36(1): e1031341. https://doi.org/10.1080/02724634.2015.1031341.

Shaffer, H.B., P. Meylan, and M.L. McKnight. 1997. Tests of turtle phylogeny: Molecular, morphological, and paleontological approaches. Systematic Biology 46(2): 235-268.

Shang, Q.-H. 2007. New information on the dentition and tooth replacement of Nothosaurus (Reptilia: Sauropterygia). Paleoworld 16(1-3): 254-263.

Shang, Q.-H., and C. Li. 2015. A new small-sized eosauropterygian (Diapsida: Sauropterygia) from the Middle Triassic of Luoping, Yunnan, southwestern China. Vertebrata PalAsiatica 53(4): $265-280$.

Smith, A.S. 2007. Anatomy and Systematics of the Rhomaleosauridae (Sauropterygia: Plesiosauria). $\mathrm{PhD}$ Thesis, University College Dublin, Dublin.

Smith, A.S. 2013. Morphology of the caudal vertebrae in Rhomaleosaurus zetlandicus and a review of the evidence for a tail fin in Plesiosauria. Paludicola 9(3): 144-158.

Smith, A.S., and G.J. Dyke. 2008. The skull of the giant predatory pliosaur Rhomaleosaurus cramptoni: Implications for plesiosaur phylogenetics. Naturwissenschaften 95(10): 975-980.

Snover, M.L., and A.G.J. Rhodin. 2008. Comparative ontogenetic and phylogenetic aspects of chelonian chondro-osseous growth and skeletochronology. In Biology of turtles, eds. J. Wyneken, M.H. Godfrey, and V. Bels, 17-43. Boca Raton: CRC Press.
Storrs, G.W. 1993. Function and phylogeny in sauropterygian (Diapsida) evolution. American Journal of Science 293: 63-90.

Sues, H.-D. 1987. Postcranial skeleton of Pistosaurus and interrelationships of the Sauropterygia (Diapsida). Zoological Journal of the Linnean Society 90: 109-131.

Tarlo, L.B. 1958. The scapula of Pliosaurus macromerus Phillips. Palaeontology 1: 193-199.

Tarsitano, S., and J. Riess. 1982. Plesiosaur locomotion: Underwater flight versus rowing. Neues Jahrbuch für Geologie und Paläontologie, Abhandlungen 164: 188-192.

Taylor, M.A. 1981. Plesiosaurs: Rigging and ballasting. Nature 290(5808): 628-629.

Taylor, M.A. 1989. Sea-saurians for sceptics. Nature 338(6217): 625-626.

Thewissen, J.G.M., and M.A. Taylor. 2007. Aquatic adaptations in the limbs of amniotes. In Fins into limbs: Evolution, development, and transformation, ed. B.K. Hall, 310-322. Chicago, Ill.: The University of Chicago Press.

Troelsen, P.V., D.M. Wilkinson, M. Seddighi, D.R. Allanson, and P.L. Falkingham. 2019. Functional morphology and hydrodynamics of plesiosaur necks: Does size matter? Journal of Vertebrate Paleontology. https://doi.org/10.1080/02724634.2019.1594850.

Vincent, P., N. Bardet, X. Pereda Suberbiola, B. Bouya, M. Amaghzaz, and S. Meslouh. 2011. Zarafasaura oceanis, a new elasmosaurid (Reptilia: Sauropterygia) from the Maastrichtian Phosphates of Morocco and the palaeobiogeography of latest Cretaceous plesiosaurs. Gondwana Research 19(4): 1062-1073.

Vincent, P., N. Bardet, A. Houssaye, M. Amaghzaz, and S. Meslouh. 2013. New plesiosaur specimens from the Maastrichtian phosphates of Morocco and their implications for the ecology of the latest Cretaceous marine apex predators. Gondwana Research 24(2): 796-805.

Walker, W.F. 1971. Swimming in sea turtles of the family Cheloniidae. Copeia 1971(2): 229-233.

Walker, W.F. 1973. The locomotor apparatus of Testudines. In Biology of reptilia, vol. 4, eds. C. Gans and T.S. Parsons, 1-100. New York, N.Y.: Academic Press.

Walker, J.A., and M.W. Westneat. 2000. Mechanical performance of aquatic rowing and flying. Proceedings of the Royal Society of London (B: Biological Sciences) 267(1455): 1875-1881.

Walker, J.A., and M.W. Westneat. 2002. Kinematics, dynamics, and energetics of rowing and flapping propulsion in fishes. Integrative and Comparative Biology 42(5): 1032-1043.

Wang, Z., J. Pascual-Anaya, A. Zadissa, W. Li, Y. Niimura, Z. Huang, C. Li, S. White, Z. Xiong, D. Fang, B. Wang, Y. Ming, Y. Chen, Y. Zheng, S. Kuraku, M. Pignatelli, J. Herrero, K. Beal, M. Nozawa, Q. Li, J. Wang, H. Zhang, L. Yu, S. Shigenobu, J. Liu, P. Flicek, S. Searle, S. Kuratani, Y. Yin, B. Aken, G. Zhang, and N. Irie. 2013. The draft genomes of soft-shell turtle and green sea turtle yield insights into the development and evolution of the turtle-specific body plan. Nature Genetics 45(6): 701-706.

Watson, D.M.S. 1924. The elasmosaurid shoulder-girdle and fore-limb. Proceedings of the Zoological Society of London 58: 885-917.

Williston, S.W. 1914. Water reptiles of the past and present. Chicago, Ill.: University of Chicago Press.

Wings, O. 2007. A review of gastrolith function with implications for fossil vertebrates and a revised classification. Acta Palaeontologica Polonica 52(1): 1-16.

Wintrich, T., S. Hayashi, A. Houssaye, Y. Nakajima, and P.M. Sander. 2017a. A Triassic plesiosaur skeleton and bone histology inform on evolution of a unique body plan. Science Advances 3(12): e1701144. https://doi.org/10.1126/sciadv.1701144.

Wintrich, T., M. Scaal, and P.M. Sander. 2017b. Foramina in plesiosaur cervical centra indicate a specialized vascular system. Fossil Record 20(2): 279-290. 
Witzel, U.W., A. Krahl, and P.M. Sander. 2015. Hydrodynamische Untersuchung des Schimmvorgangs eines jurassischen Plesiosauriers: Bestimmung des Körperwiderstands und der Vortriebskräfte der Flossen. In 86. Jahrestagung der Paläontologischen Gesellschaft e. V. vom 14.-16. September 2015 in LandsweilerReden (Saarland). ZfB-Scriptum (Veröffentlichungen des Zentrums für Biodokumentation) 4: 58.

Wyneken, J. 1997. Sea turtle locomotion: Mechanisms, behavior, and energetics. In The biology of sea turtles, vol. 1, eds. P.L. Lutz and J.A. Musick, 165-198. Boca Raton: CRC Press.

Wyneken, J. 2001. The anatomy of sea turtles. NOAA Technical Memorandum, NMFS-SEFSC 470: 1-172.
Zhang, Q., W. Wen, S. Hu, M.J. Benton, C. Zhou, T. Xie, T. Lü, J. Huang, B. Choo, Z.-Q. Chen, and J. Liu. 2014. Nothosaur foraging tracks from the Middle Triassic of southwestern China. Nature Communications 5: 3973. https://doi.org/10.1038/ncomm s4973.

Zug, G.R., A.H. Wynn, and C. Ruckdeschel. 1986. Age determination of loggerhead sea turtles, Caretta caretta, by incremental growth marks in the skeleton. Smithsonian Contributions to Zoology 427: 1-34. 